\title{
ECONOMIC MIGRATION GONE WRONG: TRAFFICKING IN PERSONS THROUGH THE LENS OF GENDER, LABOR, AND GLOBALIZATION
}

\author{
Dr. Dana Raigrodski, University of Washington School of Law \\ More often than not, "trafficking is labor migration gone horribly \\ wrong in our globalized economy."1
}

\section{INTRODUCTION}

The last decade brought much needed attention to the global plight of human trafficking, as numerous members of vulnerable populations are trafficked all over the world to be enslaved in a broad range of industries including, but far from limited to, commercial sex. Yet, the global community's efforts to successfully mitigate trafficking and protect those most likely to fall victim to it continue to fall short. This Article argues that the lack of success in fighting human trafficking is to a large extent the result of framing the existing discourse of human trafficking as primarily a matter of criminal law and human rights of women and children rather than addressing the economic and global market conditions within which human trafficking thrives. It is, as Jonathan Todres puts it, a design failure rather than an implementation failure. ${ }^{2}$

This Article further suggests that the almost exclusive focus on criminal and human rights discourse developed in response to the paradigmatic story of human trafficking-young women or children being duped and kidnapped for exploitation-in the illegal commercial sex industry. However, that focus continues to marginalize the impact on the role of women, children, and migrant workers from developing nations in the global economy. We will not be able to mitigate human trafficking or to achieve economic and social equality around the world without acknowledging the gendered and class underpinnings of human trafficking discourse.

\footnotetext{
${ }^{1}$ Janie Chuang, Beyond a Snapshot: Preventing Human Trafficking in the Global Economy, 13 Ind. J. Global Legal Stud. 137, 138 (2006) [hereinafter Preventing Human Trafficking].

2 Jonathan Todres, Widening Our Lens: Incorporating Essential Perspectives in the Fights Against Human Trafficking, 33 MicH. J. INT’L L. 53, 55 (2011) [hereinafter Incorporating Perspectives] (exploring alternative perspectives to the criminal law model of human trafficking, including a human rights perspective, a public health perspective, and a development perspective). See also Jonathan Todres, Moving Upstream: The Merits of Public Health Law Approach to Human Trafficking, 89 N.C. L. REV. 447 (2011) (discussing the limitations of the current legislative framework).
}

http://dx.doi.org/10.18060/7909.0006 
Recent efforts link human trafficking to economic pull and push factors exacerbated by globalization and trade liberalization, but very little discourse frames the discussion in those terms. The current discourse on trafficking fails to admit that human trafficking is the "underside of globalization." There is no willingness to admit that human trafficking greases the wheels of the global economy. Instead, this Article argues for an economic analysis of human trafficking which primarily looks at globalization, trade liberalization, and labor migration as the core areas that need to be explored to advance the prevention of human trafficking.

Part I briefly examines the prevailing criminal law enforcement framework regarding human trafficking - both at the international level and in the United States-which stems out of viewing human trafficking as primarily a threat to global security and an underground industry of transnational criminal enterprises. It argues that while criminalization no doubt helped bring much needed attention (and resources) to human trafficking, the narrow criminal law focus fails to address the root causes of human trafficking and will not be able to prevent human trafficking.

Part II looks at the complementary human rights framework to combat human trafficking. It briefly explores the early human rights discourse regarding trafficking and its limitations, the concerns over the criminal law emphasis of the trafficking protocol and Trafficking Victims Protection Act (TVPA), and the efforts in the past decade to re-infuse the human rights approach and to strengthen the protection and services provided to trafficking victims. It argues that the human rights framework is likely to remain very limited in its ability to push governments and private sector stakeholders to action because it continues to evoke the early discourse focusing on the protection of women and children and fails to recognize the global economic impetus of human trafficking.

Part III examines closely the gendered nature of the current human trafficking discourse. It argues that the criminal enforcement efforts and the human rights approaches are unsuccessful in combating human trafficking in large part because these efforts remain focused on sex trafficking of women and children as the paradigm. That dominant narrative, however, serves as a double-edged sword. While the narrative emphasizes the plight of many women and children and the need to "rescue" them from the traffickers, it is less likely to garner the firm international and domestic commitment and resources needed for true preventative measures as long as it is viewed as a women's issue. The focus on the enslavement of women and children in the illegal sex industry by criminal organizations allows us to view human trafficking as an aberration rather than acknowledge the central role it plays in supporting and maintaining the global economy; and, it continues to marginalize both the impact on and the role of women, children, and migrant workers from developing nations in the global economy.

Part IV offers a close examination of the realities of labor and 
migration in the era of globalization. It specifically highlights the vulnerabilities to trafficking and exploitation brought upon by globalization, the feminization of labor migration, and the links between irregular migration and human trafficking. Consequently, in Part V, the article suggests the need to develop an economic analysis of human trafficking, one which primarily looks at globalization, trade liberalization, and labor migration as the core areas that need to be explored to prevent human trafficking.

\section{HUMAN TRAFFICKING AND CRIMINAL LAW DISCOURSE: THE ORIGINS OF THE CURRENT LEGAL FRAMEWORKS TO COMBAT TRAFFICKING}

"Human trafficking" was not defined in international, regional, and national laws ${ }^{3}$ until the late 2000s when the United Nations (U.N.) finally adopted the Protocol to Prevent, Suppress, and Punish Trafficking in Persons, Especially Women and Children, ${ }^{4}$ and the United States enacted the TVPA, ${ }^{5}$ in recognition of the modern-day alarming rise in the trade-in and enslavement of millions of people around the world. While various legal instruments already existed to address certain aspects of the problem, it was clear that various slavery-like practices including, but not limited to,

\footnotetext{
${ }^{3}$ Several international legal instruments have already incorporated and addressed the need to eliminate trafficking (at least sex trafficking of women and children), but did so without clearly defining what trafficking is. See e.g. International Agreement for the Suppression of the White Slave Traffic, opened for signature May 4, 1904, 1 L.N.T.S. 83, amended by a Protocol approved by the U.N. General Assembly on Dec. 3, 1948, 30 U.N.T.S. 23 (entered into force Jul. 18, 1905); International Convention for the Suppression of the White Slave Traffic, opened for signature May 4, 1910, 3 L.N.T.S. 278, amended by a Protocol approved by the U.N. General Assembly on Dec. 3, 1948, 30 U.N.T.S. 23 (entered into force Aug. 8, 1912); International Convention for the Suppression of Traffic in Women and Children, opened for signature Sept. 30, 1921, 9 L.N.T.S. 415 (entered into force Jun. 15, 1922); International Convention for the Suppression of Traffic in Women of Full Age, opened for signature Oct. 11, 1933, 150 L.N.T.S. 431 (entered into force Aug. 24, 1934); Convention for the Suppression of the Traffic in Persons and of the Exploitation of the Prostitution of Others, opened for signature Dec. 2, 1949, 96 U.N.T.S. 271 (entered into force Jul. 25, 1951).

${ }^{4}$ See, e.g., Protocol to Prevent, Suppress and Punish Trafficking in Persons, Especially Women and Children, Supplementing the United Nations Convention Against Transnational Organized Crime, opened for signature Nov. 15, 2000, 2237 U.N.T.S. 319 (entered into force Dec. 25, 2003) [hereinafter Trafficking Protocol].

${ }^{5}$ See Trafficking Victims Protection Act of 2000, Division A of Pub. L. No. 106-386, 114 Stat. 464 (2000), reauthorized by the Trafficking Victims Protection Reauthorization Act of 2003, Pub. L. No. 108-193, 117 Stat. 2875, reauthorized by the Trafficking Victims Protection Reauthorization Act of 2005, Pub. L. No. 109-164, 119 Stat. 3558 (2006), the William Wilberforce Trafficking Victims Protection Reauthorization Act of 2008, Pub. L. No. 110-457, 122 Stat. 5054, and in Title XII of the Violence Against Women Reauthorization Act of 2013, Pub. L. No. 113-4, 127 Stat. 54 (2013); See also 22 U.S.C. §§ 7101-7112 (codifying most of the human trafficking laws in the United States).
} 
forced labor, child labor, debt bondage, and commercial sexual exploitation of children and adults were thriving with impunity in many parts of the world. ${ }^{6}$ The international framework and the U.S. framework called for the criminalization of all acts of human trafficking and envisioned that governmental response should incorporate the 3Ps: prevention, criminal prosecution, and victim protection. ${ }^{7}$

While all three components have been recognized as essential, they have not been equal, neither in design nor in implementation. ${ }^{8}$ From the start, as will be demonstrated below, much of the contemporary discourse and resources focused on criminal enforcement and security issues posed by illegal human trafficking. Accordingly, the foremost obligation on nations and states (under the Trafficking Protocol, European Union (EU) and other regional instruments, TVPA, or State law) is to take legislative and other measures to criminalize conduct amounting to trafficking in persons, and prosecute traffickers.

Historically, the limited attention to human trafficking was driven by moral-based and human rights concerns regarding mostly white women and children. ${ }^{9}$ In contrast, the prompt for the series of meetings convened by the U.N. in Vienna in the late 1990s, which eventually led to the adoption of the Trafficking Protocol, was the identified link between trafficking, migrant smuggling, transnational organized crime, and the threat to global security. ${ }^{10}$ Having viewed human trafficking as a growing enterprise of transnational organized crime, the Trafficking Protocol itself was developed as a supplement to the U.N. Convention Against Transnational Organized Crimes, ${ }^{11}$ helping to facilitate cooperation among states in the investigations and prosecutions of transnational crime including trafficking in persons. ${ }^{12}$ The most concrete obligation on signatory states, stated in Article 5, is to take legislative and other measures to criminalize conduct

\footnotetext{
6 Anne T. Gallagher, The International Law of Human Trafficking 1-2 (2010) [hereinafter GALLAGHER].

${ }^{7}$ Trafficking Protocol, supra note 4, art. 5. "Trafficking in Persons” under the Protocol is defined in art. 3. Id. art 3; See also 22 U.S.C. §§ 7102-7106.

${ }^{8}$ Incorporating Perspectives, supra note 2, at 56-57.

${ }^{9}$ See infra Part II.A.

10 Gallagher, supra note 6, at 68. The international community quickly determined it needed to reach an agreement to facilitate the collaborative fight against transnational organized crime. Id. at 1, 68. Dr. Anne Gallagher, who at the time served as a U.N. Official representing the U.N. High Commissioner for Human Rights in those meetings, recalls a conversation with a very senior delegate who viewed this not as a human rights issue but as the need of governments to cooperate in order to catch the traffickers, whom he viewed as criminals. Id. at 2.

${ }^{11}$ United Nations Convention Against Transnational Organized Crime, opened for signature Nov. 15, 2000, 2225 U.N.T.S. 209, (entered into force Dec. 25, 2003) [hereinafter Organized Crime Convention].

${ }^{12}$ Id. art. 1.
} 
amounting to trafficking in persons. ${ }^{13}$ Other articles in the Protocol, such as Article 10 (dealing with information sharing and training for law enforcement and immigration authorities), Article 11 (dealing with measures to increase border security), and Articles 12 and 13 (dealing with security of travel documents) again underscore the core focus of the Organized Crime Convention and Trafficking Protocol on global security and transnational criminal law enforcement. ${ }^{14}$

The regional and national legal frameworks that developed in the decade that followed placed much of the same emphasis on the criminalization of human trafficking and the prosecution and punishment of traffickers. The EU 2002 Framework Decision on Combatting Trafficking in Human Beings ${ }^{15}$ retained and expanded the Trafficking Protocol's criminal justice focus. ${ }^{16}$ The Preamble to the later Directive 2011/36/EU of the European Parliament and of the Council of Europe on preventing and combating trafficking in human beings and protecting its victims, and replacing Council Framework Decision 2002/629/JHA also begins by stating that "[t]rafficking in human beings is a serious crime, often committed within the framework of organized crime . . ."17 before delineating the law enforcement priorities for the EU.

The TVPA reflects the central focus of the criminal law enforcement approach to combating trafficking in the United States. ${ }^{18}$ While the United States had various laws on the books addressing forced labor, involuntary servitude, sex trafficking of children, etc., it was clear that existing legislation, law enforcement, and sentencing guidelines in the United States were "inadequate to deter trafficking and bring traffickers to justice, failing to reflect the gravity of the offenses involved." 19 As noted in the Congressional findings, "[n]o comprehensive law exists in the United States that penalizes the range of offenses involved in the trafficking scheme."20 The TVPA included significant amendments to Chapter 77 of Title 18 to the United States Code, which defines various crimes of peonage, slavery,

\footnotetext{
${ }^{13}$ Trafficking Protocol, supra note 4, art. 5.

${ }^{14}$ Protocol to Prevent, Suppress and Punish Trafficking in Persons, Especially Women and Children, Supplementing the United Nations Convention Against Transnational Organized Crime, opened for signature Nov. 15, 2000, 2237 U.N.T.S. 319 (entered into force Dec. 25, 2003) [hereinafter Trafficking Protocol]

15 See Council Decision of 19 Jul. 2002 on Combatting Trafficking in Human Beings (2002/629/JHA), 2002 O.J. (L 203/1).

16 See Gallagher, supra note 6, at 96-99 (providing a detailed discussion of the EU Framework Decision on Trafficking in Human Beings).

${ }^{17}$ European Parliament and Council Directive of 5 Apr. 2011 on Preventing and Combating Trafficking in Human Beings and Protecting its Victims, Replacing EU Council Framework Decision 2002/629/JHA (2011/36/EU), 2011 O.J. (L 101/1).

${ }^{18}$ See infra notes 20-27 and accompanying text.

1922 U.S.C. § 7101(b)(14-15) (2012).

2022 U.S.C. § 7101(b)(14-15) (2012).
} 
and trafficking in persons, ${ }^{21}$ as well as to the sentencing guidelines. ${ }^{22}$ Since the passage of TVPA, all fifty states have followed with similar legislation criminalizing the various forms of human trafficking. ${ }^{23}$ Federal and state law enforcement agencies now place the investigation, prosecution, and sanctioning of traffickers high on their agenda, devoting significant resources and training opportunities to that task. ${ }^{24}$

Particularly telling are the ways in which the law enforcement approach frames the United States' globally-applicable "minimum standards for the elimination of trafficking" and its engagement with other governments on this issue. ${ }^{25}$ The "minimum standards for the elimination of trafficking" set out in TVPA require foreign governments to prohibit trafficking and punish acts of trafficking, and to make serious and sustained efforts to eliminate trafficking. ${ }^{26}$ The Act also sets out criteria that "should be considered" as indicia of "serious and sustained efforts to eliminate trafficking"; the first of which is whether the government vigorously investigates and prosecutes acts of trafficking within its territory. ${ }^{27}$ Countries are then placed into one of the report's three tiers based upon these countries' governmental efforts to combat trafficking. ${ }^{28}$

${ }^{21}$ See Trafficking Victims Protection Act of 2000, Division A, Sec. 112(a) of Pub. L. No. 106-386, 114 Stat. 464 (2000) (focusing on strengthening the prosecution and punishment of traffickers). For example, Sec. 112(a) increased the maximum sentence for crimes of peonage, 18 U.S.C. § 1581a (2000), and enticement to slavery, 18 U.S.C. § 1583 (2000), sale into involuntary servitude, 18 U.S.C. $§ 1584$ (2000) from 10 to 20 years, and possibly life. More importantly, it specifically added the crimes of forced labor, 18 U.S.C. § 1589 (2000), Trafficking with respect to peonage, slavery, involuntary servitude, or forced labor, 18 U.S.C. § 1590 (2000), Sex trafficking of children or by force, fraud or coercion, 18 U.S.C. § 1591 (2000), and Unlawful conduct with respect to documents in furtherance of trafficking, peonage, slavery, involuntary servitude, or forced labor, 18 U.S.C. § 1592 (2000).

${ }^{22}$ Trafficking Victims Protection Act of 2000, Division A, Sec. 112(b) of Pub. L. No. 106386, 114 Stat. 464 (2000), codified as 22 U.S.C. § 7109 (2000).

23 Policy Advocacy, THE POLARIS PROJECT, http://www.polarisproject.org/what-we-do/policyadvocacy (listing a comprehensive survey of each state's existing and pending legislation).

24 U.S. Dept. State, Trafficking in Persons Report 381-383 (2013), http://www.state. gov/j/tip/rls/tiprpt/2013/index.htm.

${ }^{25}$ Realizing that the U.S. efforts to eliminate trafficking depend on the level of engagement of other governments with this issue, Congress established in TVPA a framework for the U.S. government to provide assistance to, measure progress of, and potentially impose unilateral sanctions on, the governments of a country of origin, transit, or destination for victims of severe forms of trafficking. See 22 U.S.C. § 7106. Congress required the establishment of the Department of State Office to Monitor and Combat Trafficking, 22 U.S.C. § 7103(e) (2012), to assist the Secretary of State in issuing an annual assessment of other governments' efforts to combat trafficking, known as the annual Trafficking in Persons Report. 22 U.S.C. § 7103(e), 7107(b) (2012).

${ }^{26} 22$ U.S.C. § 7106(a) (2012).

2722 U.S.C. $\S 7106($ b) (2012).

2822 U.S.C. § 7107 (2012). Countries whose governments fully comply with the Act's minimum standards for the elimination of trafficking, i.e. those which criminalize and have 
There has been much critique of the United States' unilateral approach in setting its own global standards, apart from the Trafficking Protocol, and taking the role of a global sheriff in imposing those standards on other countries. ${ }^{29}$ There is little doubt, however, that most governments around the world have ceded to the U.S. regime on anti-human trafficking measures, either due to the direct support of U.S. funding and institutional resources to aid foreign governments, combat trafficking, or the somewhat effective "naming and shaming" tool that the annual Trafficking In Persons (TIP) report has become. ${ }^{30}$ Consequently, the world allocates an overwhelming majority of its legal efforts and resources to the criminalization of human trafficking, to the training of law enforcement authorities, and to the prosecution of traffickers.

Criminalization helped bring much needed attention (and funding) to this modern slavery. However, the number of prosecutions is dismally low in comparison to the scope of the problem, and the estimated numbers of people being trafficked is on the rise. ${ }^{31}$ The allocation of most resources and attention to criminal enforcement relegated the grave human rights dimensions of this growing crisis to a secondary place at best. ${ }^{32}$ Once

successfully prosecuted trafficking, and have provided a wide range of protective services to victims as well as sponsor prevention campaigns, are placed in tier 1; countries whose governments do not fully comply with those standards are placed in tier 2, if they are making "significant efforts to bring themselves into compliance" with the standards, such as countries which are strong in the prosecution of traffickers, but provide little or no assistance to victims. Id. at (b)(1) The TIP Report also places some tier 2 counties on a watch list if: a) the absolute number of victims of severe forms of trafficking is very significant or is significantly increasing; b) there is a failure to provide evidence of increasing efforts to combat severe forms of trafficking in persons from the previous year; or c) the determination that a country is making significant efforts to bring itself into compliance with minimum standards was based on commitments by the country to take additional future steps over the next year. Id. at (b)(3)(A)(iii). Lastly, countries which are not making significant efforts to bring themselves into compliance are placed in tier 3, Id. at (b)(1)(c), and may be subject to certain sanctions by the United States. 22 U.S.C. § 7107(d) (2012).

${ }^{29}$ See, e.g., Janie Chuang, The United States as Global Sheriff: Using Unilateral Sanctions to Combat Human Trafficking, 27 Mich. J. INT’L L. 437 (2005-2006) [hereinafter Global Sheriff]; GALlagher, supra note 6, at 485.

${ }^{30}$ See Global Sheriff, supra note 29, at 439. Chuang focuses her critique on the unilateral sanctions regime set up by the United States and suggests that that sanctions regime has prompted many governments to develop laws and policies to combat trafficking. Id. Contra Karen Bravo, Follow the Money? Does the International Fight Against Money Laundering Provide a Model for International Anti-Human Trafficking Efforts? 6 U. ST. THOMAS L. J. 138 (2008) (arguing that the TIP Report naming and shaming lists have had minimal impact compared to the FATF's dirty lists regarding corruption).

31 Incorporating Perspective, supra note 2, at 65-66 (comparing the low number of trafficking prosecutions worldwide, as of 2009, with the estimated growing numbers of trafficking victims).

32 Jonathan Todres, Human Rights, Labor, and the Prevention of Human Trafficking: A Response to a Labor Paradigm for Human Trafficking, 60 UCLA L. REV. Discourse 142, 151 (2013).See also Part II.B. and II.C infra. 
framed as a criminal law and security issue, it is more likely that further efforts will be anchored in a criminal law approach. ${ }^{33}$

Moreover, as will be discussed infra, ${ }^{34}$ the narrow criminal law focus fails to address the root causes of human trafficking, and hence, will not be able to prevent human trafficking. Trafficking is anything but limited to the illegal activity of criminals. To the contrary, it is the demand for products and services in legitimate industries within the dynamics of global markets which fuels the black market of trading in humans. Having realized the huge profitability of the human trafficking market, criminal enterprises and traffickers all over the world serve as the conduit connecting the never ending supply of desperate workers with the growing demand of businesses and consumers across all economic sectors for cheap products and services produced by cheap labor. The dominant narrative of trafficking as an aberrant criminal activity of "bad apples," however, serves to mask the direct complicity and significant economic benefits gained by governments, businesses, and members of society through the facilitation and furthering of exploitation through human trafficking, primarily at the expense of poor men, women, and children.

\section{THE Human Rights Discourse: Everything OlD IS NEW AgAiN}

Historically, the issue of human trafficking was addressed at the margins of international human rights discourse. Throughout the twentieth century, the international community condemned human trafficking as a grave human rights violation through various legal instruments. ${ }^{35}$ However, notwithstanding such efforts to frame human trafficking as a human rights problem, the concern over transnational criminal organizations and border security motivated governments to develop a new international legal

${ }^{33}$ Incorporating Perspective, supra note 2, at 63-64 (discussing the "anchoring effect" of the criminal law approach to combat human trafficking).

${ }^{34}$ See Part III and IV infra.

35 See Universal Declaration of Human Rights, G.A. Res. 217 (III) A, U.N. Doc. A/RES/217(III) (Dec. 10, 1948); International Covenant on Civil and Political Rights, Dec. 16, 1966, 999 U.N.T.S. 171; Supplementary Convention on the Abolition of Slavery, the Slave Trade, and Institutions and Practices Similar to Slavery, Apr. 30, 1956, 266 U.N.T.S. 3; Convention Against Torture and Other Cruel, Inhuman or Degrading Treatment or Punishment, Dec. 10, 1984, 1465 U.N.T.S. 85; Convention on the Elimination for Discrimination Against Women, opened for signature Mar. 1, 1980, 1249 U.N.T.S. 13; Convention on the Rights of Child and Its Optional Protocols (on the Sale of Children, Child Prostitution and Child Pornography and on the Involvement of Children in Armed Conflict), G.A. Res. 44/25, 44 U.N. GAOR Supp. (No. 49), U.N. Doc. A/44/49 (Nov. 20, 1989) and G.A. Res. 54/263, Annexes I, II (May 25, 2000), S. TREATY DOC. NO. 106-37 (2000); ILO Convention Concerning Forced and Compulsory Labor, opened for signature Jun. 28, 1930, 39 U.N.T.S. 55, ILO No. 29; ILO Convention Concerning the Abolition of Forced Labor, opened for signature Jun. 25, 1957, 320 U.N.T.S. 291, ILO No. 105; ILO Convention Concerning the Prohibition and Immediate Action for the Elimination of the Worst Forms of Child Labor, opened for signature Jun. 17, 1999, 2133 U.N.T.S. 161, ILO No. 182. 
framework. ${ }^{36}$ As Anne Gallagher notes, it is very possible that without the need for global collaboration on criminal enforcement, border integrity and security threats, the human rights dimension alone would not have sufficed to garner the renewed interest and agreement among the states on defining, criminalizing, and prioritizing human trafficking. ${ }^{37}$

Concerns over the criminal law emphasis of the Trafficking Protocol and TVPA led to efforts in the past decade to revive the human rights approach to trafficking and to strengthen the protection and services provided to trafficking victims. ${ }^{38}$ There has been increasing recognition amongst policy makers and human trafficking advocates that providing protective measures for trafficking victims is as important as capturing and prosecuting their traffickers; ${ }^{39}$ and there is a growing consensus within the international community about the need to address the human rights violations that trafficking brings about. ${ }^{40}$

The sections below explore the early human rights discourse regarding trafficking and its limitations, the concerns over the criminal law emphasis of the trafficking protocol and TVPA, the efforts over the past decade to re-infuse the human rights approach, and the efforts to strengthen the protection and services provided to trafficking victims. Nonetheless, this Article argues, The human rights framework is likely to remain very limited in its ability to push governments and the growing number of private sector stakeholders to action because it continues to evoke the early discourse focusing on the protection of women and children and fails to recognize the global economic impetus of human trafficking.

\section{A. Trafficking and Human Rights Discourse in the Early Twentieth Century - Focusing on White Women and Children Exploited in the Commercial Sex Industry}

While recent efforts to combat human trafficking go back only to the late 1990s, human trafficking is not a new phenomenon. The late-nineteenth and early-twentieth centuries saw the use of the term "human trafficking" in

\footnotetext{
${ }^{36}$ See Part I supra.

${ }^{37}$ GALLAGHER, supra note 6, at 4-5.

${ }^{38}$ See Part II.B and Part II.C infra.

${ }^{39}$ See Youla Haddadin \& Ilona Klímová-Alexander, Human Rights-Based Approach to Trafficking: The Work of the United Nations Office of the High Commissioner for Human Rights, 52 No. 1 Judges' J. 22, 22 (2013). See also forward by former Secretary of State Hillary Clinton to the 2012 TIP Report, U.S. DePt. State, Trafficking IN PERsons RePORT 2 (2012), http://www.state.gov/j/tip/rls/tiprpt/2012/index.htm ("We should aim not only to put an end to this crime, but also to ensure that survivors can move beyond their exploitation and live the lives they choose for themselves.”).

${ }^{40}$ See, e,g., Youla Haddadin \& Ilona Klímová-Alexander, Human Rights-Based Approach to Trafficking: The Work of the United Nations Office of the High Commissioner for Human Rights, 52 No. 1 JuDGEs’ J. 22, 22 (2013).
} 
connection with the forcible or fraudulent recruitment of white women or girls into commercial sex work. $^{41}$ Both the 1904 White Slavery Convention ${ }^{42}$ and the 1910 White Slavery Convention, ${ }^{43}$ for example, were intended to combat the coerced criminal procurement of women and girls for "immoral purposes." 44 The term "white slavery" referred only to sex trafficking, and was specifically defined to distinguish it from the earlier widespread practice of (African) slave trade. ${ }^{45}$

Although references to "white slavery" diminished, ${ }^{46}$ the focus on the coerced sexual exploitation of innocent young women and children across borders remained core to subsequent conventions, and continues to remain the core of the discourse to date. ${ }^{47}$ The 1921 International Convention for the Suppression of Traffic in Women and Children ${ }^{48}$ avoided references to "white slavery" and applied to boys and girls under the age of twenty-one, and to older women if they were coerced into "immoral" sex work. The 1933 International Convention for the Suppression of Traffic in Women of Full Age ${ }^{49}$ eliminated the notion of consent and applied to the trafficking of women of any age across international borders for immoral purposes. The 1949 Convention for the Suppression of the Traffic in Persons and of the Exploitation of the Prostitution of Others, ${ }^{50}$ which consolidated the various earlier instruments, applies to men and women (in title as well), but remains limited to trafficking for prostitution.

The Preamble to the 1949 Convention established a direct link to the

${ }^{41}$ GALLAGHER, supra note 6, at 13.

42 International Agreement for the Suppression of the White Slave Traffic, opened for signature May 4, 1904, 1 L.N.T.S. 83, amended by a Protocol approved by the U.N. General Assembly on Dec. 3, 1948, 30 U.N.T.S. 23 (entered into force Jul. 18, 1905).

${ }^{43}$ International Convention for the Suppression of the White Slave Traffic, opened for signature May 4, 1910, 3 L.N.T.S. 278, amended by a Protocol approved by the U.N. General Assembly on Dec. 3, 1948, 30 U.N.T.S. 23 (entered into force Aug. 8, 1912).

${ }^{44}$ See Art. I and Art. II of the International Agreement for the Suppression of the White Slave Traffic, opened for signature May 4, 1904, 1 L.N.T.S. 83, amended by a Protocol approved by the U.N. General Assembly on Dec. 3, 1948, 30 U.N.T.S. 23 (entered into force Jul. 18, 1905); Art I. and Art. II of the International Convention for the Suppression of the White Slave Traffic, opened for signature May 4, 1910, 3 L.N.T.S. 278, amended by a Protocol approved by the U.N. General Assembly on Dec. 3, 1948, 30 U.N.T.S. 23 (entered into force Aug. 8, 1912).

${ }^{45}$ GALLAGHER, supra note 6, at 55.

${ }^{46}$ See infra notes 48-57 and accompanying text.

${ }^{47}$ See infra Part III.

${ }^{48}$ International Convention for the Suppression of Traffic in Women and Children, opened for signature Sept. 30, 1921, 9 L.N.T.S. 415 (entered into force Jun. 15, 1922).

${ }^{49}$ International Convention for the Suppression of Traffic in Women of Full Age, opened for signature Oct. 11, 1933, 150 L.N.T.S. 431 (entered into force Aug. 24, 1934).

50 Convention for the Suppression of the Traffic in Persons and of the Exploitation of the Prostitution of Others, opened for signature Dec. 2, 1949, 96 U.N.T.S. 271 (entered into force Jul. 25, 1951). 
"dignity and worth of the human being," which neither trafficking nor prostitution is compatible. ${ }^{51}$ In addition to prosecution and punishment measures, protection and rehabilitation of victims are key concepts, including fair treatment of foreign victims in the proceedings against their traffickers, ${ }^{52}$ the provision of certain social services, ${ }^{53}$ and care for destitute victims prior to repatriation. ${ }^{54}$ The 1949 Convention receives much criticism for denying women their agency, and for not truly taking a human rights approach. ${ }^{55}$

For thirty years, the 1949 Convention served as the only international agreement on trafficking. It was finally supplemented in 1979 with the passage of the Convention on the Elimination of All Forms of Discrimination Against Women (CEDAW) ${ }^{56}$ and the passage of the Convention on the Rights of the Child (CRC) in $1989 .{ }^{57}$ Both addressed a broad scope of coerced and exploitative practices involving women and children and calling for the elimination of all forms of trafficking against women and children. Other international human rights instruments addressing abusive and exploitive work conditions for migrant workers ${ }^{58}$

${ }^{51}$ Convention for the Suppression of the Traffic in Persons and of the Exploitation of the Prostitution of Others, at Preamble, opened for signature Dec. 2, 1949, 96 U.N.T.S. 271 (entered into force Jul. 25, 1951).

${ }^{52} I d$. at art. 14.

${ }^{53} \mathrm{Id}$. at art. 16.

${ }^{54}$ Id. at art. $19(1)$.

55 A discussion of the debate surrounding women's agency and choice, prostitution, and the abolitionist approach taken by most of the international and domestic legal instruments is beyond the scope of this Article. For more detailed discussion and further sources, See GALLAGHER, supra note 6, at 55, 61-62.

${ }^{56}$ Convention on the Elimination of All Forms of Discrimination Against Women, opened for signature Dec. 13, 1979, 1249 U.N.T.S. 13 (entered into force Sept. 3, 1981), art. 6 at 17.

57 Convention on the Rights of the Child, opened for signature Nov. 20, 1989, 1577 U.N.T.S. 3 (entered into force Sept. 2, 1990), art. 35, 36.

58 See ILO Convention No. 143, Concerning Migration in Abusive Conditions and the Promotion of Equality of Opportunity and Treatment of Migrant Workers, opened for signature Jun. 24, 1975, 1120 U.N.T.S. 324 (entered into force Dec. 9, 1978). The other eight core ILO conventions, as well as another ILO Convention specifically protecting migrant workers, are also relevant in the context of trafficking. See Convention Concerning Forced and Compulsory Labour, opened for signature Jun. 28, 1930, 39 U.N.T.S. 55, ILO No. 29 (entered into force May 1, 1932); Convention Concerning Freedom of Association and Protection of the Rights to Organize, opened for signature Jul. 9, 1948, 68 U.N.T.S. 17, ILO No. 87 (entered into force Jul. 4, 1950); Convention Concerning Right to Organize and Collective Bargaining, opened for signature Jul. 1, 1949, 96 U.N.T.S. 257, ILO No. 98 (entered into force Jul. 18, 1951); Convention Concerning Equal Remuneration for Men and Women Workers for Work of Equal Value, opened for signature Jun. 19, 1951, 165 U.N.T.S. 303, ILO No. 100 (entered into force May 23, 1953); Convention Concerning the Abolition of Labour, opened for signature Jun. 25, 1957, 320 U.N.T.S. 291, ILO No. 105 (entered into force Jan. 17, 1959); Convention Concerning Discrimination in Respect of Employment and Occupation, opened for signature June 25, 1958, 362 U.N.T.S. 31, ILO No. 11 (entered into force Jun. 15, 1960); Convention Concerning Minimum Age for 
would also have potential applicability to trafficking victims, but the connection between trafficking and migrant labor was not directly drawn until recently. ${ }^{59}$

The inherent political, legal, and structural weaknesses of the international human rights system resulted in few effective solutions to human trafficking during most of the twentieth century. ${ }^{60}$ During the second half of the twentieth century, the States' reporting obligations and overall enforcement mechanism under the 1949 Convention proved to be extremely weak, ${ }^{61}$ and the concern over innocent women and girls being taken abroad and forced against their will into situations of (typically sexual) exploitation was "almost exclusively confined to the margins of the relatively low-profile human rights system." ${ }^{2}$ Despite fairly straightforward prohibitions in two major treaties and an array of related standards in other human rights conventions, it was, and still is, extremely difficult to link trafficking to the violation of a specific provision of a specific convention. ${ }^{63}$

The scope of trafficking did not disappear however; to the contrary, it kept growing at an alarming rate. Eventually, the chronic inability of human rights law and tools to deal with modern forms of exploitation and trafficking prompted States to look for more effective responses outside the human rights framework. ${ }^{64}$

\section{B. Human Rights Discourse and the Trafficking Protocol}

Many in the human rights community were concerned that the drafting of the first modern international legal instrument on trafficking was vested in the U.N. Crime Commission rather than the U.N. Commission on Human Rights. ${ }^{65}$ In trying to ensure that a human rights perspective was injected into the criminal law enforcement framework, efforts were taken to convince States that incorporating human rights protections to the victims was crucial to achieving the crime and border control objectives. ${ }^{66}$

Admission to Employment, opened for signature Jun. 26, 1973, 1015 U.N.T.S. 298, ILO No. 138 (entered into force Jun. 19, 1976); Convention Concerning the Prohibition and Immediate Action for the Elimination of the Worst Forms of Child Labour, opened for signature Jun. 17, 1999, 2133 U.N.T.S. 161, ILO No. 182 (entered into force Nov. 19, 2000); Convention Concerning Migration for Employment (Revised), opened for signature Jul. 1, 1949, 20 U.N.T.S. 79, ILO No. 97 (entered into force Jan. 22, 1952).

${ }^{59}$ GALLAGHER, supra note 6, at 161-62.

${ }^{60} \mathrm{Id}$. at 4.

${ }^{61} \mathrm{Id}$. at 62.

62 Id. at 16.

${ }^{63} \mathrm{Id}$. at 4.

${ }^{64} \mathrm{Id}$. at 477.

${ }^{65}$ Id. at 4. See also Global Sheriff, supra note 29, at 446-47.

66 Gallagher, supra note 6, at 71-72. For example, it was recognized that successful investigation and prosecution of traffickers depended on the cooperation of the victims, 
Consequently, while clearly driven by concerns about global security and transnational criminal enterprises, the Trafficking Protocol also reflects an agreement amongst the international community about the severe human rights issues that human trafficking entails. ${ }^{67}$ Both the Preamble to the Protocol $^{68}$ and its Statement of Purpose ${ }^{69}$ emphasize the need to respect and protect the victims' human rights. Similarly, Article 6 (dealing with assistance and protection to trafficking victims), Article 7 (dealing with the status of trafficking victims in receiving states), and Article 8 (dealing with repatriation of trafficking victims) specify specific areas of focus for the states to address, from immediate medical, counseling, ${ }^{70}$ and housing needs, ${ }^{71}$ to long-term education, ${ }^{72}$ employment, ${ }^{73}$ and residency status assistance. $^{74}$

As many critics have noted, most of the requirements do not place "hard" detailed obligations on States. ${ }^{75}$ States do not breach their international obligations, if they provide no assistance whatsoever to trafficking victims. ${ }^{76}$ The question is whether this flaw in the Trafficking Protocol can be remedied by the already existing, though underutilized, protections in general international human rights law, and by subsequent legal developments. ${ }^{77}$

\section{Human Rights Discourse and the Call for Better Protection of Trafficking Victims}

There is no doubt that human trafficking presents grave human rights issues. ${ }^{78}$ Since the enactment of the Trafficking Protocol, there has been increasing recognition that protective measures for trafficking victims are as important, if not more so, than capturing and prosecuting their traffickers. ${ }^{79}$

which in turn requires measures to protect their rights and provide much needed services. Id. at 83; See also, the U.S. Department of Homeland Security victim-centered approach under its Blue Campaign, available at http://www.dhs.gov/blue-campaign/about-blue-campaign.

${ }^{67}$ See infra notes 68-74 and accompanying text.

${ }^{68}$ Trafficking Protocol, supra note 4, pmbl.

${ }^{69} \mathrm{Id}$. art. 2.

${ }^{70} \mathrm{Id}$. art. 6.3(c)

${ }^{71}$ Id. art. 6.3(a)

${ }^{72} \mathrm{Id}$. art. 6.3(d)

${ }^{73} \mathrm{Id}$. art. 6.3(d)

${ }^{74}$ Id. art. 7.

${ }^{75}$ See GALlAGHER, supra note 6, at 81-82.

${ }^{76} \mathrm{Id}$. at 83.

${ }^{77} \mathrm{Id}$. at 2.

${ }^{78}$ See, e.g., 22 U.S.C. § 7101(b)(23); GALLAGHER, supra note 6, at 5 ("Trafficking goes to the very heart of what human rights law is trying to prevent.").

79 See Youla Haddadin \& Ilona Klímová-Alexander, Human Rights-Based Approach to Trafficking: The Work of the United Nations Office of the High Commissioner for Human Rights, 52 No. 1 Judges' J. 22, 22 (2013). See also infra notes 80-94 and accompanying text. 
Both the European approach to human trafficking ${ }^{80}$ and the slowlychanging focus in the implementation of the U.S. TVPA demonstrate the growing consensus of the need to address the human rights violations that trafficking brings about. ${ }^{81}$

The current European approach to human trafficking focuses more directly on the human rights issues than does the Trafficking Protocol. The 2005 Council of Europe Convention on Action against Trafficking in Human Beings ${ }^{82}$ (Convention) set out to be, in contrast to the Trafficking Protocol, a human rights instrument with a core focus on victim protection. ${ }^{83}$ It is a comprehensive treaty focusing mainly on the protection of victims of trafficking and the safeguarding of their rights. ${ }^{84}$ In designing, implementing, and assessing policies and programs to prevent trafficking, the Convention required member countries to promote a human rightsbased approach and to use a gender mainstreaming and child-sensitive approach. ${ }^{85}$ Accordingly, Chapter III of the European Trafficking Convention sets up specific measures to protect and promote the rights of victims and to guarantee gender equality. ${ }^{86}$

${ }^{80}$ See infra notes 82-86 and accompanying text.

${ }^{81}$ As former Secretary of State Hillary Clinton pointed out in the 2012 TIP Report:

Trafficking in persons deprives victims of their most basic freedom: to determine their own future. Our work in fulfilling the promise of freedom should be not only the pursuit of justice, but also a restoring of what was taken away. We should aim not only to put an end to this crime, but also to ensure that survivors can move beyond their exploitation and live the lives they choose for themselves.

U.S. Dept. State, TrafFicking in Persons Report 2 (2012), http://www.state. gov/j/tip/rls/tiprpt/2012/index.htm.

${ }^{82}$ Council of Europe Convention on Action Against Trafficking in Human Beings and its Explanatory Report, CETS 197, 16.V.2005, opened for signature May 16, 2005, entered into force Feb. 1, 2008 [hereinafter European Trafficking Convention]. See also GaLlaGHER, supra note 6, at 110-27 (offering a detailed discussion of the drafting process and scope of the Council of Europe Convention Against Trafficking).

${ }^{83}$ GALLAGHER, supra note 6, at 114.

${ }^{84}$ As stated in the Preamble, the European Trafficking Convention is based on recognition of the principle that trafficking in human beings is first and foremost a violation of human rights and an offence to the dignity and integrity of the human being. European Trafficking Convention, supra note 82, at pmbl. It therefore aims to protect the human rights of trafficking victims, design a comprehensive framework for the protection and assistance of victims and witnesses, while guaranteeing gender equality, and to ensure effective investigation and prosecution. European Trafficking Convention, supra note 82, at art. $1(1)((b)$.

${ }^{85}$ European Trafficking Convention, supra note 82, at art. 5(3).

${ }^{86}$ Such measures include, for example, correct identification of victims and postponement of any removal proceedings; identity and privacy protection; assistance to victims in their physical, psychological and social recovery including housing, medical services, translation services, counsel and assistance in the criminal proceedings against the traffickers, education for child victims, and so forth; residence permit if necessary based on the victims' personal situation or to ensure cooperation with law enforcement authorities; access to legal aid and 
The U.S. TVPA also creates hard obligations ${ }^{87}$ with regard to victims' protections and assistance, both for victims outside the United States and for victims within the United States. ${ }^{88}$ Alien trafficking victims within the United States, for example, may be eligible for federal public benefits and assistance, ${ }^{89}$ protection of their safety, and access to medical care. $^{90}$ The Trafficking Victims Protection Reauthorization Act of 2003 also created a private cause of action for trafficking victims. ${ }^{91}$ Trafficking victims may even be eligible for temporary or permanent residency status in the United States. ${ }^{92}$

Within the TVPA statutory framework, prevention comes first, then protection, and finally prosecution. As noted earlier, at the implementation stage, much of the focus and resources early on has been on the criminal enforcement aspect. ${ }^{93}$ Most TIP reports clearly put more emphasis in their assessment of efforts in other countries on legislative action to criminalize trafficking and on efforts by law enforcement agencies and the criminal

compensation; and repatriation with due regard for the victim's rights, safety and dignity. European Trafficking Convention, supra note 82, at art. 10-16.

The anchoring of the European approach in human rights law received a further boost in a 2010 landmark decision of the European Court of Human Rights. In the case of Rantsev v. Cyprus and Russia, the Court found that Cyprus and Russia were legally responsible and liable in damages for the death, in Cyprus, of a Russian woman who was most likely a trafficking victim. Eur. Ct. H. R. App. No. 25965/04 (2010), (ECHR Jan. 7, 2010), available at http:/hudoc.echr.coe.int/ sites/eng/pages/search.aspx?i=001-96549\#\{"itemid":["001-96549"]\}. The Court specifically ruled that trafficking in human beings fell within the scope of Article 4 of the European Convention for the Protection of Human Rights and Fundamental Freedoms. Id. at I 293, 309. The Court emphasized that, accordingly, States had a positive human rights obligation to put in place an appropriate legal and administrative framework against trafficking, to take measures to protect victims and to investigate acts of trafficking, including through effective co-operation with other States concerned on criminal matters. Id. at 290-309.

${ }^{87}$ Applicable only to victims of "a severe form of trafficking in persons." The term "severe forms of trafficking in persons” is defined in 22 U.S.C. § 7102(8) (2012) as:

(A) sex trafficking in which a commercial sex act is induced by force, fraud, or coercion, or in which the person induced to perform such act has not attained 18 years of age; or

(B) the recruitment, harboring, transportation, provision, or obtaining of a person for labor or services, through the use of force, fraud, or coercion for the purpose of subjection to involuntary servitude, peonage, debt bondage, or slavery.

${ }^{88}$ See 22 U.S.C. § 7105(a) (2012) and 22 U.S.C. § 7105(b) (2012).

8922 U.S.C. § 7105(b)(1) (2012).

9022 U.S.C. $\S 7105(c)(1)(B)(2012)$.

91 TVPRA of 2003, Pub. L. No. 108-193, 117 Stat. 2875, §4(a)(4)(A) (providing a private cause of action for victims to sue their individual traffickers); See also 18 U.S.C. § 1595(a) (2012) (offering an additional cause of action for trafficking victims to sue their traffickers in order to recover damages and attorneys fees).

92 See 22 U.S.C. $\S 7105(c)(3)(i)$ (2012). Immigration status, however, is contingent upon cooperation with law enforcement in prosecution efforts. See 22 U.S.C. § 7105(c)(3)(iii) (2012).

${ }^{93}$ See Part I supra. 
justice system as a whole to capture and punish traffickers. ${ }^{94}$ It was not until the 2012 TIP Report that protection of trafficking survivors took a more central role in shaping U.S. policy on trafficking. ${ }^{95}$ The 2014 TIP report underscores the U.S. commitment to support trafficking victims in their journey to becoming trafficking survivors. ${ }^{96}$

The emphasis on trafficking as a human rights issue helped shift the

94 See, e.g., U.S. DePt. Of StATE, Trafficking in Persons Report 14 (2003), available at http://www.state.gov/documents/organization/21555.pdf (discussing in the following order: prevention, prosecution, and protection). In 2004, the order became prosecution, protection, prevention, and the analysis continued in that order in 2005, 2006, 2007, 2008, 2009, 2010, and 2011. See Trafficking in Persons Report, U.S. DEPT. OF STATE, http://www.state.gov/j /tip/rls/tiprpt/index.htm (last visited Jun. 20, 2014).

As recently as the 2009 and 2010 TIP reports, prosecution and punishment were at the top of the U.S. policy priorities. See U.S. Dept. of State, Trafficking in Persons Report 25-32 (2009), available at http://www.state.gov/documents/organization/123357.pdf; See also U.S. Dept. of StAte, Trafficking in Persons Report 12 (2010), available at http://www.state.gov/documents/organization/142979.pdf. The 2009 TIP Report included an explanatory section on the "3Ps," Punishment, Protection and Prevention, See U.S. DEPT. OF State, Trafficking in Persons Report 25-32 (2009), available at http://www.state.gov/ documents/organization/123357.pdf (discussing the “3P”), and the 2010 TIP Report section on Policy Priorities stated: "Since the issuance of President Bill Clinton's Executive Memorandum on the Trafficking of Women and Children in March 1998, the U.S. government has advocated a policy structured by the "3P” paradigm: prosecution, protection, and prevention.” See also U.S. DePt. of State, Trafficking in Persons Report 12 (2010), available at http://www.state.gov/documents/organization/ 142979.pdf.

Current policy communications from the Office to Monitor and Combat Trafficking in Persons and from the President's Interagency Task Force To Monitor and Combat Trafficking in Persons suggest that a shift in focus back to prevention, protection, prosecution, and the newly added 4P ("partnership") is slowly taking place. See, e.g., Office to Monitor and Combat Trafficking in Persons, U.S. DEPT. OF STATE, http://www.state.gov /j/tip/index.htm. The fourth 'P'-Partnerships-has been included in recent TIP reports, starting with the 2010 TIP Report. The most recent reauthorization of the TVPA specifically added a section promoting collaboration and cooperation between the U.S. government, foreign governments, civil society actors, and private sector entities. See Violence Against Women Reauthorization Act of 2013, Pub. L. No. 113-4, § 1202, 127 Stat. 54 (2013) (codified as amended at 22 U.S.C. § 7103a(a) (2013)).

${ }^{95}$ See U.S. Dept. OF StATe, TrafFicking in Persons Report (2012), available at http://www.state.gov/j/tip/rls/tiprpt/2012/index.htm (focusing on how to make victim protection more effective for helping survivors restore their lives and for providing them with meaningful choices to move forward). The 2013 TIP report continues on this path, by not only focusing on effective victim identification, but most importantly by focusing on listening to survivors' experiences and incorporating their perspectives and giving survivors a true voice in the process. See U.S. Dept. of State, Trafficking in Persons Report (2013), available at http://www.state.gov/j/tip/rls/tiprpt/2013/index.htm.

96 See U.S. Dept. of StAte, Trafficking in Persons Report (2014) available at http://www.state.gov/j/tip/rls/tiprpt/2014/index.htm. The 2014 TIP report makes it clear that "a major element of the recovery process is helping victims regain their agency, their dignity, and the confidence to make choices about how to move forward with their lives.” Id. at 8 . 
perception of trafficking victims from being considered criminals themselves, subject to deportation and prosecution to being viewed as victims. ${ }^{97}$ The human rights discourse also put pressure on governments' to incorporate the Protection aspect of the "3P" paradigm; ${ }^{98}$ it now drives many public awareness campaigns and educational programs under the Prevention component of the "3P" paradigm. ${ }^{99}$ Moreover, a human rights approach continues to remind us "trafficking is woven deeply and inextricably into the fabric of an inequitable, unjust, and hypocritical world." 100

At the same time, the human rights discourse remains mostly aspirational and limited in its ability to obligate nations and businesses to take affirmative steps to address the social and economic conditions that perpetuate trafficking. There is no shortage of international human rights standards that address trafficking, but very little takes the form of concrete obligations and true engagement with the underlying issues.

The inherent limitations of the human rights and the criminal law enforcement framework to prevent human trafficking show that a new approach is needed. A few scholars have begun focusing on other possible approaches to human trafficking. ${ }^{101}$ Those emerging voices primarily take a

97 See e.g. U.S. DePT. OF STATE, TRAFFICKING IN PERSONS REPORT (2010), available at http://www.state.gov/documents/organization/142980.pdf at p.13-16 (setting a victim-centered approach as a policy priority for the U.S. anti-trafficking efforts and identifying the detentions and criminalization of victims as harmful to victims and as counterproductive.). See also U.S. DEPT. OF StAte, TrafFicking IN PERSONs RePORT (2013), available at http://www.state.gov/documents/ organization/210737.pdf at p.36 (discussing non-criminalization of victims).

98 See e.g. See U.S. DePT. Of StATE, TrafFicking In Persons RePORT (2011), available at http://www.state.gov/documents/organization/164452.pdf at p.40-42 (delineating governments' responsibility to offer comprehensive protection measures to trafficking victims). See also U.S. DePT. Of StATE, TRAFFiCKING IN PERSONS REPORT (2012), available at http://www.state.gov/ documents/organization/192587.pdf at 9-14.

99 See e.g. the mission statement of the U.N. Global Initiative to Fight Human Trafficking (UN.GIFT), available at http://www.ungift.org/knowledgehub/en/about/index.html ("UN.GIFT aims to mobilize state and non-state actors to eradicate human trafficking by reducing both the vulnerability of potential victims and the demand for exploitation in all its forms; ensuring adequate protection... while respecting the fundamental human rights of all persons...UN.GIFT will increase the knowledge and awareness on human trafficking; promote effective rights-based responses...). High profile media campaigns, for example, include the CNN Freedom Project, http://thecnnfreedomproject.blogs.cnn.com/.

${ }^{100}$ GALLAGHER, supra note 6, at 4.

${ }^{101}$ See e.g., Sarah Richelson, Trafficking and Trade: How Regional Trade Agreements Can Combat the Trafficking of Persons in Brazil, 25 ARIZ. J. INT'L \& COMP. L. 857 (2008)(suggesting the integration of labor and other human rights into free trade agreements as a new approach to combat human trafficking); Karen E. Bravo, Free Labor! A Labor Liberalization Solution to Modern Trafficking in Humans, 18 TRANSNAT'L L. \& CONTEMP. PROBS. 545, 562 (2009) (arguing that human capital and labor should be able to move freely in the global economy, similar to other goods and services, thus undermining the incentives for underground mu=migration and human trafficking) [hereinafter Free Labor]; James Gray 
labor approach or, to a lesser extent, a development approach and a public health approach. ${ }^{102}$ Common to all these approaches, as well as to this Article, is the recognition that human trafficking thrives on the vulnerability of certain individuals and populations to exploitation and the call to investigate the relations between labor migration and human trafficking. ${ }^{103}$

It is now time to recognize the limitations of the current approaches and address the problem as a matter of economic development and sustainability. To do so, however, we need to specifically examine the gendered nature of the current discourse. As this article argues in Part III infra, the current discourse on human trafficking is gendered in several ways. On the one hand, criminal enforcement efforts and the human rights approaches remain focused on sex trafficking of women and children as the paradigm. On the other hand, the focus on the enslavement of women and children in the illegal sex industry by criminal organizations allows us to view human trafficking as an aberration rather than acknowledge the central role it plays in supporting and maintaining the global economy. Consequently, the current discourse continues to marginalize both the impact on and the role of women, children, and migrant workers from developing nations in the global economy.

\section{A PRoblematic GENDERED DisCOURSE: THE Focus ON WOMEN AND CHILDREN}

Part I and II supra argued that the discourse on human trafficking has been too narrow, and consequently ineffective, due to its focus on criminal law enforcement and on human rights. This part asserts that the current discourse has also been narrow in its primary focus on women and children, and, up until recently, on sex trafficking. It is largely due to that focus that we have not been able to truly address and hopefully prevent human

Pope, A Free Labor Approach to Human Trafficking, 158 U. PA. L. REV. 1849 (2010) (focusing on the empowerment of workers to claim their rights); Jonathan Todres, Widening Our Lens: Incorporating Essential Perspectives in the Fights Against Human Trafficking, 33 MicH. J. INT'L L. 53, 55 (2011) (exploring alternative perspectives to the criminal law model of human trafficking including a human rights perspective, a public health perspective, and a development perspective); Jonathan Todres, Moving Upstream: The Merits of Public Health Law Approach to Human Trafficking, 89 N.C. L. REV. 447 (2011)(further exploring a public health approach to human trafficking); Hila Shamir, A Labor Paradigm for Human Trafficking, 60 UCLA L. REV. 76 (2012) (examining human trafficking through a labor lens and suggesting workplace measures to empower employees)[hereinafter A Labor Paradigm]; Jonathan Todres, Human Rights, Labor, and the Prevention of Human Trafficking: A Response to a Labor Paradigm for Human Trafficking, 60 UCLA L. REV. Discourse 142 (2013)(supporting a combined human rights and labor approach to combat human trafficking).

102 See infra Part V.

${ }^{103} \mathrm{Id}$. 
trafficking.

The historical legacy of initially excluding people of color from the early trafficking protections and of conceptualizing trafficking as only relating to sex trafficking of women and children is reflected in the current legal framework and discourse regarding trafficking. ${ }^{104}$ Whether directly reflected in their names, or indirectly underlying the legal framework, much of the current approaches to human trafficking developed in response to the paradigmatic horror story of human trafficking - the young (white) woman or child being duped and kidnapped for exploitation in the illegal commercial sex industry. ${ }^{105}$ The Protocol to Prevent, Suppress, and Punish Trafficking in Persons, Especially Women and Children (emphasis added) was initially intended to deal only with trafficking in women and children. However, a proposal to expand the scope to all persons was made early on, and almost all the States agreed, with the understanding that particular attention should be given to the protection of women and children. ${ }^{106}$ The question of whether to move beyond the traditional focus on sex trafficking to include forced labor, debt bondage, and forced marriage garnered much more opposition. ${ }^{107}$ Much of the discourse in Europe and in Asia in the 1990s and to some extent today, shows a clear preference to define trafficking as restricted to the sexual exploitation of women and children. ${ }^{108}$ The TVPA, which in 2000 was part of a legislative package addressing violence against women, similarly elevates trafficking in the form of sexual exploitation of women and children. ${ }^{109}$ Today as well, portrayals of human trafficking in the media (including in documentary and fiction movies), advocacy campaigns by NGOs, and on social networks, demonstrate that the history of the human trafficking discourse-especially the narrative envisioning the rescue of innocent women and girls from life of enslavement in immoral sexual activities-continue to shape the current human trafficking discourse. ${ }^{110}$

104 See supra Part II.A.

105 See infra notes 106-110 and accompanying text.

${ }^{106}$ GALLAGHER, supra note 6, at 26.

107 GALLAGHER, supra note 6, at 26-29.

${ }^{108}$ Id. at $19-22$.

109 TVPA separately identifies "sex trafficking” as a severe form of trafficking if procured by fraud or coercion, or if involving minors. 22 U.S.C. § 7102 (2012). Of the twenty-four Congressional findings that frame TVPA, five findings reference sex trafficking and the commercial sex industry and five findings refer specifically to women and children as victims of trafficking, primarily in sexual exploitation. 22 U.S.C. § 7101 (2012). The 2013 reauthorization of TVPA was again as part of the reauthorization of VAWA. See Title XII of the Violence Against Women Reauthorization Act of 2013, Pub. L. No. 113-4, 127 Stat. 54 (2013).

${ }^{110}$ UN.GIFT maintains a list of many documentary and fiction films on human trafficking (http://www.ungift.org/knowledgehub/media/films.html, archived at PERMA). Of the better known ones are the three Taken Hollywood movies (2008, 2012, 2014), Sex Traffic (2004), 
That dominant narrative, however, serves as a double-edged sword. While the narrative emphasizes the plight of many women and children and the need to 'rescue' them from the traffickers, as long as it is viewed as a women's issue it is less likely, as we have unfortunately seen in many other areas, to garner the firm international and domestic commitment and resources needed for true preventative measures. Since many trafficked women and men are often also poor migrant individuals of color from the Global South, their marginalization and invisibility goes beyond gender issues and is compounded by the intersection of multiple characteristics that are devalued, historically, and within the current global power structures.

Jonathan Todres' analysis of "otherness" and "othering" in the context of trafficking is particularly insightful. In his article Law, Otherness and Human Trafficking, ${ }^{111}$ Todres suggests that "otherness," which inherently devalues and dehumanizes the "Other," facilitates the abuse and exploitation of certain individuals and explains, at a regulatory level, both the current selective responses to exploitation and trafficking and complete inaction in various regards. ${ }^{112}$ The intersections of race, gender, ethnicity, class, culture, and geography leads members of dominant backgrounds (either as individuals or as groups or even countries) to devalue and "other" certain individuals, communities and entire nations. ${ }^{113}$ Poor women of color in developing countries are persistently subject to "othering" on multiple dimensions, and tend to be the most marginalized and devalued within the global community. ${ }^{114}$ The more marginalized they are, the more they are at risk of exploitation. ${ }^{115}$ The more limited their choices are because of their race, gender, ethnicity, class, culture, or geography, the more they may opt to engage in risky work or risk dangerous paths. ${ }^{116}$

"Othering" also allows the global community, especially the Global

Trafficked (2005), Human Trafficking (2005), Daryl Hannah's human trafficking documentary (2006), Not for Sale (2007), Redlight (2009), and Not My Life (2010). With the exception of Not My Life, these movies focus on sex trafficking of women and children and the efforts to rescue them.

NGO examples include: THORN, formerly the DNA Foundation founded by Demi and Ashton Kutcher, which focuses on combating the digital/online sexual exploitation of women and children (http://www.demiandashton.com/aboutus/, archived at PERMA); the Coalition Against Trafficking in Women, http://www.catwinternational.org/, which is a multi-regional international network fighting sexual exploitation and prostitution (http://www.catwinternational.org/, archived at PERMA); End Child Prostitution, Child Pornography and Trafficking of Children for Sexual Purposes (ECPAT), which is another NGO and a global network of civil society organizations exclusively dedicated to ending the commercial sexual exploitation of children, (http://www.ecpat.net/, archived at PERMA).

111 Jonathan Todres, Law, Otherness, and Human Trafficking, 49 SANTA Clara L. ReV. 605 (2009).

112 Id. at 607.

${ }^{113} \mathrm{Id}$. at 609 .

${ }^{114}$ Id. at $619-20$.

115 Id. at 621-22.

${ }^{116}$ Id. at 622 . 
North, to, on the one hand, view itself as the altruistic savior of the "Other," and, on the other hand, to rationalize and turn a blind eye to its own exploitation and benefit at the expense of the "Other." 117 The focus on the enslavement of women and children in the illegal sex industry by criminal organizations allows us to view human trafficking as an aberration rather than acknowledge the central role it plays in supporting and maintaining the global economy. ${ }^{118}$ It continues to marginalize both the impact on and the role of women, children, and migrant workers, primarily from developing nations, in the global economy. As may often be the case, "trafficked women may be . . . migrant women attempting to meet their own needs or responding to labor demand in the West." ${ }^{119}$ But, the dominant trafficking narrative ignores the complex structural, social, and economic aspects of women's labor migration. ${ }^{120}$

As long as the focus remains on "saving" women and children from the hands of criminals, instead of acknowledging the global economic realities that feed and perpetuate the business of human trafficking, our efforts will continue to be a drop in the sea. I join Jonathan Todres in suggesting that it is precisely because those most vulnerable to-and directly harmed by—human trafficking are impoverished migrant women, children and men of color-i.e. "The Other"-that the discourse has been allowed to remain in the marginalized and weaker international law domain of human rights and labor rights rather than at the core of economic growth and trade policies.

\section{THE REALITIES OF ECONOMIC MigRATION AND HUMAN TRAFFICKING IN THE ERA OF GLOBALIZATION}

In an increasingly interdependent world, human migration is just another element of the global market-place. ${ }^{121}$

117 Id. at 623-35. See also Shamir, A Labor Paradigm, supra note 101, at 80-81 (“[T]he prevailing human rights approach to anti-trafficking is not merely acutely limited in its reach but in fact may also be harmful in that it has created the illusion that the international community is taking action against severe forms of exploitation, when in reality, little is being done to address the underlying causes.”).

118 As Todres demonstrates, "othering” also allows the dominant group, the "Self," to exempt its own behavior and exploitation of those it views as "Other." Todres, supra note 111 , at $616-17,623-35$.

119 Janie Chuang, Rescuing Trafficking from Ideological Capture: Prostitution Reform and Anti-Trafficking Law and Policy, 158 U. PA. L. REV. 1655, 1702 (2010) [hereinafter: Rescuing Trafficking].

${ }^{120}$ Id. See infra Part V.

121 Jennifer Chaćon, Misery and Myopia: Understanding the Failures of U.S. Efforts to Stop Human Trafficking, 74 FordHAM L. REV. 2977, 2977 (2006) [hereinafter Misery and Myopia]. 
As migrant workers, particularly migrant women, are playing an increasingly critical role in the global economy, trafficking victims are often poor unskilled migrant workers. The dominant trafficking narrative continues to marginalize the impact on, and the role of, women, children, and migrant workers, primarily from and within developing nations, in the global economy.

Many trafficked workers are enslaved in their own countries and are not necessarily cross-border migrant workers. Many may be "domestic" migrant workers from rural, less-developed areas to urban or industrial areas. Others are simply relegated to exploitive and dangerous jobs in the name of global economic development, open markets, and competitive production and supply chains. All, especially trafficked cross-border migrant workers, increasingly serve a critical role in sustaining the global economy all over the world.

\section{A. Vulnerability and Globalization}

Human trafficking feeds into a global market dependent on cheap and exploitable labor and the goods and services that such labor can produce. It is exacerbated by gender violence, poverty, and disparities in economic opportunities vis-a-vis unmet labor demands and strict migration laws in wealthier countries. As Janie Chuang aptly put it:

The problem of trafficking begins not with the traffickers themselves, but with the conditions that caused their victims to migrate under circumstances rendering them vulnerable to exploitation. Human trafficking is but "an opportunistic response" to the tension between the economic necessity to migrate, on the one hand, and the politically motivated restrictions on migration, on the other. $^{122}$

Trafficking exploits the vulnerability of certain individuals and populations, especially those seeking better economic opportunities at home or abroad. ${ }^{123}$ Amongst the factors that help shape individual's or certain group's, communities', and societies vulnerability to trafficking are poverty and lack of employment opportunities, which are often aggravated by inequality, discrimination and gender-based violence, and the lure of better economic opportunities elsewhere. ${ }^{124}$ These "push" factors are intensified

122 Preventing Human Trafficking, supra note 1, at 140.

${ }^{123}$ Incorporating Perspectives, supra note 2, at 58-59.

${ }^{124}$ GALLAGHER, supra note 6, at 415. 
by "pull" factors including ongoing and increasing demand, mostly in wealthier developed regions, for cheap goods and services. ${ }^{125}$ Desperate for any job, poor unskilled workers are willing to fill unmet labor demands in informal sectors or in jobs that are rejected by domestic workers in wealthier countries for being too dirty, dangerous, or difficult. ${ }^{126}$ At the same time, employers who seek to increase profits at the expense of vulnerable workers, "create” demand for forced labor. ${ }^{127}$ Lastly, rather than acknowledge their dependency on migrant labor in many economic sectors, destination countries, fearing the "other," respond with strict migration laws and border control, thus incentivizing trafficking. ${ }^{128}$

These push and pull factors are not new. However, they have taken center stage in the era of contemporary globalization. ${ }^{129}$ Globalization and trade liberalization led not only to greater international exchange of capital and goods, but also to increasing labor migration. ${ }^{130}$ Alongside general economic benefits, ${ }^{131}$ globalization increases the wealth gap between countries and between rich and poor within countries. ${ }^{132}$ Such wealth disparities feed increased survival labor migration as economic opportunities disappear in less wealthy countries and communities. ${ }^{133}$ Those desperate to migrate, however, encounter tightening border controls and limited options for legal migration at the destination countries (although those countries generate a growing demand for such migrant

125 Incorporating Perspectives, supra note 2, at 60 ("Ultimately, as with the drug trade, traffickers are feeding a demand driven by consumers. In the human trafficking context, the demand is driven by both the desire for commercial sex and the desire for cheap goods and services.”).

${ }^{126}$ Preventing Human Trafficking, supra note 1, at 145.

${ }^{127}$ Id. See also A Labor Paradigm, supra note 101, at 83 (“[T] here are rent-Seeking interests that benefit from flexible, deregulated labor markets. Such interests may be served by worker migration, but need labor to remain informal, thereby reducing the cost of labor and weakening workers' protections and bargaining power while increasing their vulnerability to exploitation.”).

${ }^{128}$ A Labor Paradigm, supra note 101, at 146.

${ }^{129}$ Globalization is a loosely defined set of complex economic and financial processes that have made our world economies increasingly interdependent on each other, including trade liberalization and rise "in international trade, global movement of capital, transnational commerce and investment and labor flows. . . .” IRFAN UL HAQUE, GLOBALIZATION, NEOLIBERALISM AND LABOUR 1 (Jul. 2004), available at http://unctad.org/en/Docs/osgdp 20047_en.pdf.

130 Preventing Human Trafficking, supra, note 1, at 140. Traditional sex roles and division of labor typically means that women participate in the labor market, primarily for survival, in unpaid or underpaid traditional female jobs. $I d$. Discriminatory gender practices often deprives women from access to both basic or higher education, which further limits their prospects for better paying jobs covered by labor protections. Id.

131 See generally IRFAN UL HAQUE, supra note 129, 3-5.

132 Preventing Human Trafficking, supra, note 1, at 140.

${ }^{133}$ Id. at 141. 
workers), which in turn exacerbates their vulnerability to trafficking. ${ }^{134}$

Furthermore, other aspects of globalization have also contributed to the expansion of traffickers' reach. No longer limited to individuals who fall prey to trafficking because of adverse personal circumstances, violent environment, lack of education, and no prospects for employment, "[i]ndividuals with higher education, including university qualifications and with second and third languages, that are in employment and stable relationships are now considered to be almost as vulnerable but for different reasons." ${ }^{135}$ Greater freedom of movement and ease of travel, lower-cost regional and international transport, and global communication and financial networks, combined with previously unavailable opportunities to work overseas and individuals' self-confidence enable traffickers to recruit persons who would not normally be thought of as vulnerable. ${ }^{136}$

\section{B. The Feminization of Labor and Migration}

Women comprise most of those emigrating for survival (due to both economic hardship and gender-based repression), and relatedly, the overwhelming majority among those who are exploited in the process and subject to labor trafficking. ${ }^{137}$ Women, as well as many men and children, faced with lack of jobs in their domestic markets, may opt to migrate in order to access developed markets within their region or abroad. Importantly, aside from fulfilling their own survival needs, migrant women, as well as men and children, are playing an increasingly critical role in sustaining the global economy as they fill the demand for workers particularly in informal low-wage earning economic sectors in destination countries. $^{138}$

Human trafficking is very much a manifestation of the feminization of both poverty and migration. ${ }^{139}$ Poverty and unemployment increase

\footnotetext{
${ }^{134}$ Id. at 138 .

135 GALLAGHER, supra note 6 , at 415 note 2

${ }^{136} I d$.

${ }^{137}$ Preventing Human Trafficking, supra, note 1, at 141.

${ }^{138} \mathrm{Id}$. at 143. Saskia Sassen argues that "exploited and undervalued women are active factors in the making of alternative political economies for survival, not only for their households but also for a range of economic sectors and for governments," even if they themselves do not necessarily gain anything or become empowered. Saskia Sassen, Strategic Gendering As Capability: One Lens into the Complexity of Powerlessness, 19 COLUM. J. GENDER \& L. 179, 180 (2010) [hereinafter Complexity of Powerlessness].

139 See generally Alyson Dimmitt Gnam, Mexico's Missed Opportunities to Protect Irregular Women Transmigrants: Applying a Gender Lens to Migration Law Reform, 22 PAC. RIM L. \& PoL'Y. J. 713 (2013) (focusing on the Mexico-U.S. migration corridor to demonstrate the global phenomenon of increasing numbers of job-Seeking migrant women).
} 
opportunities for trafficking in women. ${ }^{140}$ Women are especially vulnerable due to entrenched discriminatory and gender-based violence practices that relegate them to unregulated low-wage employment in informal sectors and limited opportunities for legal migration. ${ }^{141}$ Women particularly are being pushed out of developing countries due to economic, familial, and societal pressures and comprise at least fifty-six percent of the world's trafficking victims. ${ }^{142}$ In enacting TVPA in 2000, Congress was in fact cognizant of many of these aspects. ${ }^{143}$ Amongst its key findings, Congress recognized that traffickers primarily target women and girls who are disproportionately affected by poverty, lack of access to education, chronic unemployment, low status and discrimination, and the lack of economic opportunities in countries of origin. ${ }^{144}$ Consequently, traffickers lure women and girls into their networks through false promises of decent working conditions at relatively good pay and buy children from poor families and sell them into various types of forced or bonded labor. ${ }^{145}$

Globalization has had a particularly harsh impact on women in the "Global South," and it is critical that we recognize the "systemic link between the growing presence of women from developing economies in a variety of global migration and trafficking circuits on one hand and the rise in unemployment and debt in those same economies on the other."146 Women in developing countries who may have been able to participate in the formal economy through small locally owned businesses and farms may no longer have those opportunities and lose out to cheaper imported goods. ${ }^{147}$ They are consequently pushed into the informal sector, or into low-skilled manufacturing and service jobs generated by the entrance of transnational corporations into developing economies. ${ }^{148}$ Quite often those corporations are allowed to get away with adverse working conditions and low wages in their "global assembly line." 149 Such employers may even prefer female workers from disadvantaged backgrounds as they take advantage of deeply imbedded gender subordination in traditional societies,

\footnotetext{
${ }^{140}$ U.N. Secretary-General, Traffic in Women and Girls: Rep. of the Secretary-General, ף 22, UN Doc. A/50/369 (Aug. 24, 1995) (citing the Committee on the Elimination of Discrimination Against Women 1992 General Recommendation 19, para. 14).

${ }^{141}$ Preventing Human Trafficking, supra note 1, at 141-44.

${ }^{142}$ See 2009 ILO Global Report of Forced Labour, The Cost of Coercion, at p.1, available at http://www.ilo.org/global/topics/forced-labour/publications/WCMS_106268/lang--en/index. htm. See also U.S. Dept. of StAte, Trafficking in PERSOns RePORT 34 (2010), available at http://www.state.gov/documents/organization/142979.pdf

143 See 22 U.S.C. $\S 7101$ (2012).

${ }^{144} \mathrm{Id}$.

14522 U.S.C. § 7101(b)(4) (2012).

146 Complexity of Powerlessness, supra note 138, at 193; See also Gnam, supra note 139.

${ }_{147}$ Preventing Human Trafficking, supra note 1, at 142-43.

${ }^{148} \mathrm{Id}$., at $142-43$.

${ }^{149} \mathrm{Id}$. at 143 .
} 
and assume that these workers are likely to be more submissive and less likely to resist exploitive work conditions. ${ }^{150}$

The international community has recognized the factors that feed into and facilitate human trafficking, including: (1) the increasing gaps between rich and poor both within countries and between regions, which means that many (women) have become more subject to trafficking in view of their economic circumstances and their hopes for increased income for themselves and their families; ${ }^{151}$ and (2) the increasing ease of international travel and the growing phenomenon of temporary migration for work, which means that opportunities for trafficking have increased. ${ }^{152}$ However, rather than acknowledge their dependency on migrant labor in many economic sectors, destination countries respond with strict migration laws and border control, especially with regards to working-class and so-called unskilled migrant labor, thus incentivizing trafficking. ${ }^{153}$

\section{C. (Irregular) Labor Migration and Human Trafficking}

It is increasingly acknowledged that the risk of trafficking increases when the demand for labor is undermined by migration policies that limit working-class migration. ${ }^{154}$

The dynamics of cross-border migration within the era of globalization compound and present additional catalysts for human trafficking. In the era of globalization, the logic of trade and finance may be

${ }^{150} \mathrm{Id}$. These dynamics are also very much at play when employers in destination countries take tacit advantage of subordination factors of migrant workers, due to gender, racial and language vulnerabilities, socioeconomic background and immigration status. Id. at 145-46. Saskia Sassen similarly offers an analytical framework of the strategic gendering in the global division of labor, discussing both the feminization of offshore workers, as a way to weaken unions and ensure a submissive and disempowered workforce, and the parallel use of migrant women for domestic work to facilitated professional 'no-wife' households in the global cities. Complexity of Powerlessness, supra note 138, at 179, 188-91.

${ }^{151}$ See generally Alyson Dimmitt Gnam, Mexico's Missed Opportunities to Protect Irregular Women Transmigrants: Applying a Gender Lens to Migration Law Reform, 22 PAC. RIM L. \& POL. J. 713 (2013).

152 U.N. Secretary General, Traffic in Women and Girls: Rep. of the Secretary General, q 6, U.N. Doc. A/51/306 (August 27, 1996).

153 See also Misery and Myopia, supra note 121, at 2977 (arguing that the U.S. is not a passive recipient of trafficked human beings and must acknowledge its role in generating a market for trafficking); Free Labor, supra note 101, at 568 ("In denying legal transborder mobility to the majority of human labor providers, nation states Seek to have it both ways. They employ both the rhetoric of globalization and integration, as well as the contradictory rhetoric of exclusion. At the same time, their migration policies are policies of exclusion characterized by incomplete trade liberalization and draconian immigration laws.”).

154 Julie Ham, Moving Beyond 'Supply and Demand’ Catchphrases: Assessing the uses AND Limitations of Demand-BASEd Approaches in ANTI-TrafFicking, 56 (2011). 
one of openness but "the logic of migration is one of closure." 155 With trade and investment, the wealthier Global North advocates openness whereas countries in the Global South have been more critical, at least initially. With migration, the dynamics are opposite: wealthier states try to keep migrant labor out whereas underdeveloped and developing states want to export workers and capitalize on their remittances. ${ }^{156}$

Traffickers can become one of the only avenues left to meet the demands of both employers and workers within such restrictive migration systems. ${ }^{157}$ In the face of tightening border controls and limited options for legal migration at the destination countries, those desperate to migrate for survival opt for risky underground migration channels, which puts them at much higher risks of becoming victims of human trafficking. ${ }^{158}$ Nonetheless, the international community has been reluctant to fully investigate and act upon the linkage between trafficking and migrant labor. $^{159}$ In fact, within the current legal framework dealing with trafficking, there is a clear effort to distinguish "trafficking” from "illegal migration" and "migrant smuggling." 160 The former crime involves helpless virtuous victims, whereas the latter two involve those who are complicit in their own misfortune, ignoring the realities of migration flows and human trafficking. ${ }^{161}$

As discussed earlier, the renewed interest in human trafficking in the late 1990s arose partially as this phenomenon became associated with other global criminal trends, including criminal organizations engaging in the illegal movement of migrants across borders for profit. ${ }^{162}$ The discourse began to expand and to address these issues from the perspective of migration control, border security, and organized crime. ${ }^{163}$ Although the analytical and empirical links between trafficking and migration flows started to surface, the legal discourse remained insistent on treating them as separate issues. ${ }^{164}$ The prevailing view continues to distinguish between

155 James F. Hollifield, Migration, Trade, and the Nation-State: The Myth of Globalization, 3 UCLA J. INT’L. L. \& FOREIGN AFF. 595, 597 (1998-99).

${ }^{156}$ Id.

${ }^{157}$ HAM, supra note 154 , at 56.

${ }^{158}$ Id. See also Jennifer Chaćon, Misery and Myopia, supra note 121, at 2977 (2006).

${ }^{159}$ See infra Notes 163-170 and accompanying text.

${ }^{160}$ See infra Notes 163-170 and accompanying text.

${ }^{161}$ See infra Notes 163-170 and accompanying text.

162 GALLAGHER, supra note 6, at 17.

163 See supra notes 10-12 and accompanying text.

164 For example, a report by the U.N. Secretary General elaborated on the connection between trafficking and illegal migration, but was careful to differentiate the two:

Trafficking across international borders is by definition illegal . . . The question must be asked however, whether trafficking is the same as illegal migration. It would seem that the two are related but different. Migration across frontiers without documentation does not have to be coercive or exploitive. At the same time persons can be trafficked with their consent. A 
trafficking, as the coerced and fraudulent movement for the end purpose of for-profit exploitation, and smuggling, as the facilitation of illegal movement across borders. ${ }^{165}$ The notion that smuggling is consensual and

distinction could be made I terms of the purpose for which the borders are crossed and whether movement occurs through the instrumentality of another person. Under this distinction, trafficking of women and girls would be defined in terms of the 'end goal of forcing . . . into economically and exploitive situations ... for profit ....

U.N. Secretary-General, Traffic in Women and Girls: Rep. of the Secretary-General, \17, U.N. Doc. A/50/369 (Aug. 25, 1995).

165 One clear manifestation of that view is the way in which trafficking and migrant smuggling are treated separately under the Organized Crime Convention. In addition to the adoption of the Trafficking Protocol, the Organized Crime Convention was supplemented by two additional protocols on migrant smuggling and on trade in small arms. See Protocol against the Smuggling of Migrants by Land, Sea and Air, Supplementing the United Nations Convention Against Transnational Organized Crime, opened for signature Nov. 15, 2000, 2241 U.N.T.S. 507 (entered into force Jan. 28, 2004), as amended Oct. 24, 2009 [hereinafter Migrant Smuggling Protocol]; See also Protocol against the Illicit Manufacturing of and Trafficking in Firearms, Their Parts and Components and Ammunition, Supplementing the United Nations Convention Against Transnational Organized Crime, opened for signature May 31, 2001, 2326 U.N.T.S. 208 (entered into force Jul. 3, 2005). With many European States as well as Australia and the United States experiencing a significant increase in the number of illegal migrants starting in the 1990s, the Migrant Smuggling Protocol intended to prevent and combat migrant smuggling by defining migrant smuggling as an international crime, by promoting international cooperation, and by protecting the rights of smuggled migrants. Migrant Smuggling Protocol, Id.

The Migrant Smuggling Protocol criminalizes the conduct of those who procure or otherwise facilitate the smuggling of migrants by defining smuggling as "the procurement, in order to obtain, directly or indirectly, a financial or other material benefit, of the illegal entry of a person into a State Party of which the person is not a national or a permanent resident.” Migrant Smuggling Protocol, supra note 125, at art. 3(a). This definition Seems to take a neutral position on the conduct and complicity of the smuggled migrants themselves. However, the underlying core distinction between those who are trafficked and those who are 'merely' smuggled is intimately intertwined with the dichotomy of coercion v. consent. Article 3(a) to the Trafficking Protocol defines "trafficking in persons” to mean:

the recruitment, transportation, transfer, harbouring or receipt of persons, by means of the threat or use of force or other forms of coercion, of abduction, of fraud, of deception, of the abuse of power or of a position of vulnerability or of the giving or receiving of payments or benefits to achieve the consent of a person having control over another person, for the purpose of exploitation. Exploitation shall include, at a minimum, the exploitation of the prostitution of others or other forms of sexual exploitation, forced labour or services, slavery or practices similar to slavery, servitude or the removal of organs. Trafficking Protocol, supra note 4, art. 3(a) (emphasis added).

The definition goes on to deem the victim's consent irrelevant where any of the means of coercion, deception, and abuse set forth in subparagraph (a) have been used, and in any case involving the trafficking of children. Trafficking Protocol, supra note 4, art. 3(b) and art. 3(c). The definition of smuggling stands in stark contrast to the definition of trafficking in that it leaves out any references to the means by which the procurement of the migrant to be smuggled occurs or any subsequent means to extort financial gain once the illegal entry has taken place. Compare Migrant Smuggling Protocol, Id. at art. X, with Trafficking Protocol, supra note 4, at art. X. 
does not involve coercion has underlined much of the discussion surrounding trafficking. ${ }^{166}$ That dichotomized view, however, fails to acknowledge the extreme vulnerability of migrant workers and the circumstances which bring people to take inordinate risks in trying to pursue what they believe to be better opportunities elsewhere to sustain themselves and their families. ${ }^{167}$

All over the world, adult human trafficking victims are primarily recruited by promises of legitimate employment opportunities, only to be subjected to coercion, violence, and exploitation upon arrival to their destination. ${ }^{168}$ Moreover, the realities of contemporary labor migration significantly undermine the assumption that the relations between the recruiter/smuggler and the migrant to be smuggled across the border are simply a manifestation of a business transaction in which the migrant purchases for money the illegal services of the smuggler. ${ }^{169}$ More often than not, the recruitment, transportation, transfer, harboring, or receipt of the migrant worker entails the abuse of a position of vulnerability and the desperation of those agreeing to be smuggled across borders in hope of better opportunities to survive. ${ }^{170}$

This is not to suggest that every instance of migrant smuggling amounts to human trafficking. The line is often blurred. If one looks at the end-point exploitation, “[i]n fact, many victims of human trafficking look

166 See also Free Labor, supra note 101, at 554-55. This distinction is flawed, serving to mask the often symbiotic relationship between the two types of transboundary movement by shrouding migrant smuggling and human trafficking in contrasting types of illegality and vilification, instead of placing them along a continuum of rational and less-to-more exploitative responses to the contradictory international economic and migration systems. Id. 167 Jennifer Chaćon argues, for example, that the limited impact of the TVPA and the ineffectiveness of the U.S. efforts to stop human trafficking stem from the United States doing almost nothing to develop an immigration strategy that deals with the global forces that drive migration and instead putting in place immigration laws and policies that render migrants vulnerable to exploitation and trafficking. See Misery and Myopia, supra note 121, at 2977 (2006).

168 See Sarah Richelson, Trafficking and Trade: How Regional Trade Agreements Can Combat the Trafficking of Persons in Brazil, 25 ARIZ. J. INT’L \& COMP. L. 857, 858 (2008); See also Shamir, A Labor Paradigm, supra note 101, at 105-06; Jonathan Todres, Human Rights, Labor, and the Prevention of Human Trafficking: A Response to a Labor Paradigm for Human Trafficking, 60 UCLA L. REV. Discourse 142, 145-46 (2013).

169 See e.g. U.S. Dept. State, Trafficking in PERSONS REPORT 26-29 (2011), http://www.state.gov/documents/organization/164452.pdf.

170 While there is no clear definition as to what amounts to abuse of a position of vulnerability, there is some support to a broad interpretation of the term. For example, the Explanatory Report to the European Convention on Action Against Trafficking, which reproduced the Trafficking Protocol definition, states that "the vulnerability may be of any kind, whether physical, psychological, emotional, family-related, social or economic . . . the situation can be any state of hardship in which a human being is impelled to accept being exploited." Council of Europe, Explanatory Report on the Convention on Action Against Trafficking in Human Beings, CETS 197, 16.V.2005 para. 83. 
quite like exploited agricultural laborers and factory workers, and in fact they are often one and the same." ${ }^{171}$ Trafficking depends not only on the coercive means by which the victim is obtained or held, but also on the purpose of exploitation such as sexual exploitation, forced labor or services, slavery, or practices similar to slavery and servitude. ${ }^{172}$ The prototypical narrative of trafficking, for example, tells the story of young women or parents of children who fall prey to the traffickers' promise of employment or educational opportunities abroad and consent to be illegally transported across borders only to find themselves in coerced sex work, domestic servitude, or other forms of forced labor. ${ }^{173}$ Similarly, many migrant workers find themselves held in debt bondage for a "debt" owed to their traffickers, which they supposedly incurred as a result of the cross-border, and previously consented to, smuggling. ${ }^{174}$ Both scenarios clearly fall within the definition of human trafficking, regardless of their origin as consensual smuggling. ${ }^{175}$

Rather than putting most of our efforts on maintaining these distinctions, we should focus our efforts on understanding and addressing the factors and dynamics that create economic deprivations and social conditions that limit individual choices and make individuals vulnerable to exploitation and trafficking. Furthermore, receiving countries like the United States need to recognize that current immigration and labor policies drive migrant workers underground and expose them to abuse by their recruiters, transporters, and employers. ${ }^{176}$

171 Dina Francesca Haynes, Exploitation Nation: The Thin and Grey Legal Lines between Trafficked Persons and Abused Migrant Laborers, 23 Notre Dame J.L. Ethics \& PuB. POL'y 1, 44-45 (2009).

172 Trafficking Protocol, supra note 4, art. 5. "Trafficking in Persons” under the Protocol is defined in art. 3. Id. art 3; See also 22 U.S.C. §§ 7102-7106.

173 The annual TIP reports highlight many such stories from all over the world. See e.g., U.S. Dept. State, Trafficking in Persons Report 8, 11, 14, 17, 23 (2012), http://www.state. gov/documents/organization/192587.pdf; U.S. DEPT. STATE, TrafFiCKING IN PERSONS REPORT 13, 17, 24, 29, 42, 46 (2013), http://www.state.gov/documents/organization /210737.pdf; U.S. Dept. State, Trafficking in Persons Report 15, 23, 28, 29, 40 (2014), http://www.state.gov/documents/organization/226844.pdf.

${ }^{174}$ In debt bondage or bonded labor the trafficker uses debt to keep a person under subjugation. Traffickers, recruiters and destination employers unlawfully exploit an initial debt the worker assumed as part of the terms of employment, or when workers inherit debt in more traditional systems of bonded labor (generations in South Asia), and use it to withhold wages, deduct housing and food costs, or confiscate passports and visa documents. Children and migrant workers are particularly vulnerable to this type of exploitation. See e.g. U.S. Dept. State, Trafficking in Persons Report 18-19, 26 (2007), http://www.state.gov/ documents/organization/82902.pdf.

${ }^{175}$ Cf. Free Labor, supra note 101, at 575 ("The lines between labor exploitation, migrant smuggling, and human trafficking are not clear. However, it is clear that labor exploitation and migrant smuggling are the Seedbed from which human trafficking grows.”).

${ }^{176}$ Misery and Myopia, supra note 121, at 3039. 
In conclusion, what may initially seem like illegal migration may very well amount to human trafficking; what may initially seem like consent may very quickly turn into abuse, coercion, and exploitation. More often than not, as pointed out by Janie Chuang, "trafficking is labor migration gone horribly wrong in our globalized economy." 177

\section{REFRAMING HUMAN TRAFFICKING AS A GLOBAL ECONOMIC ISSUE}

The current discourse on trafficking fails to admit that human trafficking is, as the International Labor Organization (ILO) points out, the "underside of globalization." ${ }^{178}$ There is no real commitment to reframe trafficking as a global migratory response to a global market that seeks out cheap, unregulated, and exploitable labor and the goods and services that such labor can produce. ${ }^{179}$ There is no willingness to admit that human trafficking greases the wheels of the global economy. Instead, this Article argues, we need to develop an economic analysis of human trafficking, one which primarily looks at globalization, trade liberalization, and labor migration as the core areas that need to be explored to advance the prevention of human trafficking.

Although the international community has generally recognized some of the factors that make individuals vulnerable to trafficking, there is no real acknowledgment of the economics of trafficking. While the Trafficking Protocol, for example, requires states (in an aspirational way) to "take or strengthen measures . . . to alleviate the factors that make persons, especially women and children, vulnerable to trafficking"180 as well as place "exploitation" at the core of the definition of trafficking, it does not otherwise acknowledge the economic forces and market practices that drive trafficking and labor exploitation more broadly. ${ }^{181}$ Even the ILO, which is significantly ahead of the current discourse on human trafficking, in recognizing human trafficking as a labor and migration issue, doesn't truly engage in a critical analysis of global markets, as if root causes of trafficking including "poverty, lack of employment and inefficient labour migration systems"182 exist in a vacuum.

The current approaches to human trafficking view it as distinct and exceptional extreme forms of human exploitation. They pretend not to notice that our markets perpetuate the commodification of labor and that trafficking is merely the extreme manifestation of an "entire spectrum of

\footnotetext{
177 Preventing Human Trafficking, supra note 1, at 138.

178 U.S. DePT. OF State, TRAFFicking in PERsons Report, 5 (2003).

${ }^{179}$ Preventing Human Trafficking, supra note 1, at 139; See also GALLAGHER, supra note 6, at 432; Misery and Myopia, supra note 121, at 3039.

180 Trafficking Protocol, supra note 4, art. 9(4).

${ }^{181}$ Cf. A Labor Paradigm, supra note 101, at 105.

182 InT’L. Labour Org, ILO Action Against Trafficking in Human Beings, 2 (2008).
} 
forms of economic coercion and commodification."183 As Hila Shamir points out, "the difference between exploitation of workers and trafficking is a matter of degree and not kind." 184

Accordingly, Shamir, for example, advocates for a paradigm shift to a labor approach "that targets the structure of labor markets prone to severely exploitative labor practices.” 185 She focuses on workers' vulnerability, the power disparities between workers and employers, and workers' inferior bargaining power in the workplace. Her labor approach calls for policies to empower workers vis-à-vis their employers, including protective employment legislation and expansion of collective action and unions. ${ }^{186}$

Shamir's labor approach is premised exactly on the understanding that "the trafficked individual is a worker who is exploited in a market context." 187 She is absolutely correct in arguing that we need to understand human trafficking as "an issue of economic labor market exploitation," 188 and to focus on power disparities and economic and social conditions that exacerbate vulnerability to trafficking. ${ }^{189}$ She acknowledges that to fully understand how power relations in the labor market operate we need to investigate, amongst other things, private market rules, immigration regimes, and trade policies. ${ }^{190}$ With that in mind, this Article argues that a true confrontation of the exploitive market dynamics that perpetuate trafficking requires a major shift in how we structure our global economy and the whole spectrum of our market practices. Shamir's efforts to ameliorate the power disparities between vulnerable workers and their employer simply do not go far enough.

Similarly, focusing on labor flows within the global economy, Karen Bravo's call to apply economic and trade liberalization principles to labor migration and human trafficking begins to engage in a true inquiry of our global market structures. ${ }^{191}$ Recognizing that "the modern traffic in human beings cannot be separated from the forces of globalization," 192 she argues

\footnotetext{
${ }^{183}$ A Labor Paradigm, supra note 101, at 110.

${ }^{184} \mathrm{Id}$.

${ }^{185} \mathrm{Id}$. at 76.

${ }^{186}$ Id. at 108. Shamir proposes five labor-focused anti-trafficking measures: prevent the criminalization and deportation of workers who report exploitation to ensure workers' access to the justice system; eliminate visa arrangements binding workers to specific employers; regulate debt-based contracting; reduce recruitment fees and the power of middlemen; guarantee the right to unionize; and extend and enforce the application of labor and employment laws to vulnerable workers and to sectors susceptible to trafficking. Id. at 11219.

${ }^{187} \mathrm{Id}$. at 106.

${ }^{188} \mathrm{Id}$. at 80 .

${ }^{189} \mathrm{Id}$. at 81.

${ }^{190} \mathrm{Id}$. at 81-82.

${ }^{191}$ Free Labor, supra note 101, at 545.

192 Id. at 549.
} 
that the only way to undermine the structural foundations of human trafficking is to "target the economic bases of the labor and other exploitation." 193 Specifically, argues Bravo, we need to acknowledge the connection between the growing problem of human trafficking, the increase in trade liberalization and globalization, and the simultaneous closing of borders and state imposition of restrictions on labor migration. ${ }^{194}$ Consequently, labor should receive the same "free mobility" status as that of other goods, capital, and services in the international trading system. ${ }^{195}$

While the opening of markets under the contemporary trade liberalization global framework removed barriers to the trans-border movement of capital, goods, and services, labor is the only production factor that has not been similarly liberalized. ${ }^{196}$ On the one hand, labor is clearly treated as a commodity in the global production chains in the race for cheap and efficient production and for profit maximization. ${ }^{197}$ On the other hand, labor is treated as a passive immobile economic unit and constrained by state borders and restrictive immigration policies. ${ }^{198}$ Moreover, the international trade regime facilitates the movement of some labor - that of skilled workers. ${ }^{199}$ By leaving out the movement of unskilled workers, whose labor is nonetheless much in demand, the international trade regime creates the economic incentives for human trafficking and increases (unskilled) labor providers' vulnerability to exploitation. ${ }^{200}$ Therefore, in order to successfully fight against human trafficking, argues Bravo, we should recognize labor's role in the global economic system and give human capital (labor) analogous status to other production and economic inputs within the international open trade system. ${ }^{201}$

Bravo is amongst the few who recognized early on that human trafficking takes place within the legitimate economic activities rather than just being limited to illegal and aberrational activity. ${ }^{202}$ She correctly observes how restrictive immigration policies perpetuate the exploitation of migrants and would-be migrants while allowing entire industries, both legitimate and illegal, to flourish financially. ${ }^{203}$ Bravo remains amongst the

\footnotetext{
${ }^{193}$ Id.

${ }^{194}$ Id. at 550, 560-61.

${ }^{195}$ Id. at 550-51. Bravo suggests doing so by adopting a new multilateral annex to the WTO Agreement - the General Agreement on Trade in Labor (GATL). Id. at 550-51, 597-607.

${ }^{196}$ Id. at 563-64.

${ }^{197}$ Id. at 562-63.

198 Id. at 563-64.

${ }^{199} \mathrm{Id}$. at 575 ("The status quo in the transnational labor market is a system of exploitation that is fatal to the poor, vulnerable, and unskilled, existing alongside a more flexible and open regime for highly skilled labor.”).

${ }^{200} I d$. at $568,571-72$.

${ }^{201} \mathrm{Id}$. at 597.

${ }^{202} I d$. at $550,561-62$.

${ }^{203}$ Id. at 597 .
} 
few who directly confront the international trade regime in an effort to undermine the economic foundations of human trafficking, ${ }^{204}$ even if it requires radical rethinking of transnational relations. ${ }^{205}$

Bravo's trade and labor market analysis, however, is primarily focused on liberalizing and regulating the supply of workers. ${ }^{206}$ While she does, of course, explicitly acknowledge that the global labor market distortion is tied to the demand for cheap labor, she nonetheless claims that "it is the vulnerability of human labor providers to that demand that allows human trafficking to flourish.”207 Therefore, although exploitation is not likely to completely cease, Bravo does think that by severely decreasing the potential supply, human trafficking will become an aberrational practice. ${ }^{208}$

This Article suggests that this is not likely to be the case, exactly because the demand for exploitable cheap labor, both domestically and across borders, is a structural feature of our liberalized, global economy and converging production chains. Labor exploitation, and with it human trafficking, is needed to sustain open markets, international trade, and the global economy. Until we are willing to admit the true costs of globalization and until we are willing to redistribute wealth allocation between nations and within nations, human trafficking will continue to increase.

In a global market that seeks out cheap, unregulated, and exploitable labor to produce goods and services that generate GDP and propel economic growth, human trafficking is anything but limited to the illegal activity of criminals. ${ }^{209}$ Trafficking of people is not merely part of the shadow economy but is in fact part of the structured global economy and serves leading economic sectors and places worldwide. ${ }^{210}$ Countries compete in the global marketplace to offer other countries and multinational

\footnotetext{
${ }^{204}$ Id. at 616.

205 Id. at 607.

206 See supra notes 191-201 and accompanying text.

${ }^{207}$ Free Labor, supra note 101, at 608.

${ }^{208}$ Id. at 608.

${ }^{209}$ Preventing Human Trafficking, supra note 1, at 139; See also GALLAGHER, supra note 6, at 432; Misery and Myopia, supra note 121, at 3039.

210 See Anne T. Gallagher, Understanding Exploitation, Vol. XXXIII, No. 3 HarV. InT’L REV. 4-5 (Fall 2011), available at http://works.bepress.com/cgi/viewcontent.cgi?article= $1021 \&$ context=anne_gallagher. No country is exempt from the pandemic of human trafficking: The main region for forced labor is by far Asia and the Pacific, and in the industrialized world, the Middle East and transition economies the majority of forced laborers are also trafficking victims. Jens Lerche, A Global Alliance against Forced Labour? Unfree Labour, Neo-Liberal Globalization and the International Labour Organization, 7(4) J. OF AgraRian CHANGE 425, 427-429 (2007). For a full exploration of how the global economy is sustained on the back of exploited and trafficked labor See Dana Raigrodski, Economic Growth on the Backs of Human Trafficking Victims - The Dependency of Global Trade and Economic Development on Forced Labor and the Trafficking of Humans, (forthcoming 2015) (on file with author).
} 
businesses the cheapest and exploitable labor. ${ }^{211}$ The economies of developing and under-developed regions benefit from exploiting and exporting their populations as cheap labor in various ways. Migrant wage remittance, including from forced and trafficked labor, accounts for a huge part of the GDP in many such nations, and entire communities and some governments are increasingly dependent on those remittances. ${ }^{212}$ The economic growth and global market competitiveness of countries such as BRICS countries, which may be exporting cheaply produced products and raw materials to fulfill demand in countries with much higher production costs, depend on their ability to continue to produce significantly cheaper products, quite often at the expenses of those people in these countries who are doing the work. ${ }^{213}$

Similarly, some governments continue to relax labor protections in order to attract foreign investment and transnational corporations who prefer to use the cheaper labor services in those countries. ${ }^{214}$ Transit

211 Ruben J. Garcia, Labor as Property: Guestworkers, International Trade, and the Democracy Deficit, 10 J. Gender, RACE AND Just. 27, 29 (2006).

212 See Saskia Sassen, Strategic Gendering As Capability: One Lens into the Complexity of Powerlessness, 19 Colum. J. Gender \& L. 179, 191 (2010) ("many governments are increasingly dependent on their remittance...through their work and remittances, migrants enhance the government revenue of deeply indebted countries.”). Of the 300 billion dollars generated annually by migrant worker remittance, possibly as high as $20 \%$ goes off to pay traffickers/recruiters commission and debt bondage. U.S. DEPT. OF STATE, TrAFFICKING IN PERSONS REPORT 22(2008), available at http://www.state.gov/documents/organization/ 105501.pdf.

213 See Ruben J. Garcia, Labor as Property: Guestworkers, International Trade, and the Democracy Deficit, 10 J. GENDER, RACE AND Just. 27, 29 (2006) ("The new sources of comparative advantage in the global economy is cheap labor"). Whereas the concept of "comparative advantage" in international trade initially referred to countries trading commodities, natural resources and raw materials in the global marketplace, we have now commodified the labor of workers in poor countries. Id. at 33. See also Don Wells, "Best Practices" in Regulation of International Labor Standards: Lessons of the U.S.-Cambodia Textile Agreement, 27 COMP. LAB. L. \& POL'y J 357, 357 (2006) (“employers use lower labor standards as a source of comparative advantage").

214 Cf. Preventing Human Trafficking, supra note 1, at 143-144 (arguing that poor governments turn a blind eye to the exploitation of local labor by foreign companies).

India's development, for example, aggressively relied on cheap and exploitable labor in both the formal and informal employment sectors. Government development policies, supported by Indian employers and accelerated since liberalization in the 1990s, encouraged (1) non-unionized docile workforce contributing more than $60 \%$ of the GDP; (2) manufacturing and services based on cheap unskilled labor, allowing for short term labor and unregulated employment relations; (3) absolute poverty of labor in the informal economy; (4) industry restructuring shifting certain sectors, such as the textile production, to the informal sector and outside the realm of labor laws; and (5) significant control of employers over the unorganized workers. Jens Lerche, A Global Alliance against Forced Labour? Unfree Labour, Neo-Liberal Globalization and the International Labour Organization, 7(4) J. OF Agrarian Change 425, 443-444 (2007). Such policies significantly increase the susceptibility of workers to human trafficking. Id. at 444. 
countries benefit economically from the flows of trafficking which utilize available services for transportation, telecommunication, hospitality, and banking; ${ }^{215}$ human trafficking directly contributes to the revenue of those industries, which are regularly used by traffickers in the recruitment, transportation, transfer, harboring or receipt of trafficking victims. ${ }^{216}$ Lastly, with much of the economic industries of wealthier destination countries depending on cheap, often migrant labor, on the one hand, but with most countries refusing to formally recognize these economic realities and ease restrictions on legal migration flows for all forms of labor, on the other hand, most of the demand for labor is met through the underground economy including human trafficking. ${ }^{217}$

Much like the cross Atlantic slave trade that sustained the economy of the United States and other nations prior to the abolition of slavery, so does our global economy continue to grow on the backs of these modern slaves, except now they are hidden from sight. Until and unless we acknowledge that the global economy thrives on the vulnerability of certain individuals and populations to exploitation, we will not be able to truly address human trafficking.

215 See Saskia Sassen, Strategic Gendering As Capability: One Lens into the Complexity of Powerlessness, 19 Colum. J. Gender \& L. 179, 180, 196 (2010).

${ }^{216} I d$.

217 See Preventing Human Trafficking, supra note 1, at 140 and Free Labor, supra note 101, at 597; supra notes 125-128 and 154-158 and accompanying text. See also Raigrodski, supra note 210. 